\title{
RECIPROCITY, NON-DISCRIMINATION AND PREFERENTIAL AGREEMENTS IN THE MULTILATERAL TRADING SYSTEM
}

Kyle Bagwell

Robert W. Staiger

Working Paper 5932

\author{
NATIONAL BUREAU OF ECONOMIC RESEARCH \\ 1050 Massachusetts Avenue \\ Cambridge, MA 02138 \\ February 1997
}

We thank Jagdish Bhagwati, Avinash Dixit, Ron Findlay, John Jackson, Giovanni Maggi, T.N. Srinivasan and seminar participants at Boston College, Columbia, Michigan, NYU, Penn, UBC, UCSD, UT-Austin, UWO and Yale for very helpful comments. This paper was completed while Staiger was a Fellow at the Center for Advanced Studies in the Behavioral Sciences. Staiger is also grateful for financial support provided by the National Science Foundation Grant \#SBR-9022192. This paper is part of NBER's research program in International Trade and Investment. Any opinions expressed are those of the authors and not those of the National Bureau of Economic Research.

(C) 1997 by Kyle Bagwell and Robert W. Staiger. All rights reserved. Short sections of text, not to exceed two paragraphs, may be quoted without explicit permission provided that full credit, including $(\mathcal{C}$ notice, is given to the source. 
Reciprocity, Non-discrimination and Preferential

Agreements in the Multilateral Trading System

Kyle Bagwell and Robert W. Staiger

NBER Working Paper No. 5932

February 1997

JEL Nos. F02, F13, F15

International Trade and Investment

\begin{abstract}
We present a framework for understanding and interpreting reciprocity and nondiscrimination, the two principles that are the pillars of the multilateral trading system as embodied in GATT and its successor, the WTO. We show that GATT's principle of reciprocity serves to neutralize the world-price effects of a country's trade policy decisions, and hence can deliver efficient trade-policy outcomes for its member governments provided that the externalities associated with trade intervention travel through world prices. We then establish that externalities indeed travel in this way if and only if tariffs also conform to the principle of non-discrimination (MFN). In this way, the principles of reciprocity and non-discrimination can work in concert to deliver efficient outcomes for the multilateral trading system. We also consider within our framework the implications of preferential agreements for the multilateral trading system. The introduction of free trade agreements complicates the way in which externalities are transmitted across countries, and in this environment the principle of reciprocity can no longer deliver efficient multilateral outcomes for its member governments. We do find, however, a limited place for customs unions in the multilateral trading system, provided that the member countries of the union have similar political preferences. As these conditions are quite stringent, we offer little support for the hypothesis that the principle of reciprocity can deliver an efficient multilateral trade agreement in the presence of preferential agreements. Instead, our results offer support for the view that preferential agreements pose a threat to the existing multilateral system.
\end{abstract}

Kyle Bagwell

Department of Economics

Northwestern University

2003 Sheridan Road

Evanston, IL 60208-2600
Robert W. Staiger

Department of Economics

University of Wisconsin

1180 Observatory Drive

Madison, WI 53706

and NBER

rstaiger@facstaff.wisc.edu 


\section{Introduction}

In the preamble to GATT, the governments of the original contracting parties to the agreement state their specific objectives and the arrangements under GATT that are expected to contribute to these objectives. The preamble states: ${ }^{1}$

"Recognizing that their relations in the field of trade and economic endeavor should be conducted with a view of raising standards of living, ensuring full employment and a large and steadily growing volume of real income and effective demand, developing the full use of the resources of the world and expanding the production and exchange of goods,

"Being desirous of contributing to these objectives by entering into reciprocal and mutually advantageous arrangements directed to the substantial reduction of tariffs and other barriers to trade and to the elimination of discriminatory treatment in international commerce,

"Have through their Representatives agreed as follows:" (GATT, Preamble).

It is notable that governments do not set forth the goal of free trade; instead, governments advocate the less ambitious goals of reciprocity (i.e., "reciprocal and mutually advantageous arrangements directed to the substantial reduction of tariffs and other barriers to trade") and non-discrimination (i.e., "the elimination of discriminatory treatment in international commerce"). While the principles of reciprocity and non-discrimination (MFN) are the pillars upon which the GATT system is erected, it is also notable that the governments agree in GATT Article XXIV to grant an important exception to MFN. This article provides conditions under which countries may form preferential agreements, which can be established as free trade areas (in which member countries eliminate their internal barriers to trade) or customs unions (in which member countries also set common external tariffs).

These observations present four questions to economists studying reciprocal trade agreements. First, and most fundamentally, what can governments hope to accomplish with reciprocal trade agreements that they cannot achieve when they set their trade policies

unilaterally? Second, given that free trade is not the stated objective of governments in GATT, can they nevertheless expect an arrangement that advocates reciprocal tariff liberalization to be mutually advantageous? Third, are their mutual goals best advanced by an agreement that eliminates discriminatory treatment? And fourth, once the principle of non-discrimination is

\footnotetext{
${ }^{1}$ A similar preamble is included in the WTO, the successor organization to GATT.
} 
adopted, can exceptions to this principle be granted for the creation of preferential agreements without compromising the performance of the multilateral system?

Our purpose in this paper is to explore these four questions within a unified framework. We adopt the view that governments enter into reciprocal trade agreements in order to achieve higher welfare than they would receive were policies set unilaterally. We do not assume, however, that government welfare is given by national income; instead, we allow that the government welfare function embodies both "economic" (i.e., national income) and "political" (i.e., distributional) considerations. Of course, a trade agreement can offer higher welfare for its participants only if an inefficiency arises when trade policies are set unilaterally. We thus begin by identifying the key inefficiency that accounts for the appeal of a reciprocal trade agreement. This provides a foundation from which to next assess GATT as an institution that is designed to facilitate the implementation of more efficient trade outcomes. In particular, we evaluate whether three of GATT's central features - reciprocity, non-discrimination (MFN) and the exception to MFN associated with the formation of preferential agreements - serve well as principles that guide participating governments to efficient outcomes.

We begin, then, with the first question identified above: Why do governments negotiate reciprocal trade agreements? A popular view is that such agreements are attractive to governments as a means to achieve political objectives. While actual governments clearly have political motivations, it is important to emphasize that this by itself provides no reason for governments to seek reciprocal trade agreements. The possibility of mutual gains from such agreements requires something more: the unilateral trade policy decisions of each government, when viewed together, must be inefficient in light of the governments' own preferences. In the leading political-economy models of trade, the introduction of politics affects the preferences of governments - for example, politically motivated governments may not aspire to free trade - but does not generate an externality across governments. As such, politics can affect the tradepolicy objectives that governments have, but it does not explain why governments need a reciprocal trade agreement in order to achieve these objectives.

An alternative view is that governments enter into reciprocal trade agreements in order to escape from a terms-of-trade driven Prisoners' Dilemma. When a government imposes an import tariff, it lowers the world price and harms foreign exporters; as a consequence of this terms-of-trade externality, governments' unilateral trade policies restrict trade more than is 
efficient. A reciprocal trade agreement can then be appealing to governments as a means to "undo" the restrictions in trade associated with the terms-of-trade externality, so that more efficient trade volumes can by achieved. This view has a long history, dating back to Torrens (1844), Mill (1844), Scitovsky (1942) and Johnson (1953-54), who developed their arguments in the context of national-income maximizing governments that exploited their monopoly power in international markets with "optimal tariffs." 2 While the terms-of-trade view is logically unassailable, many economists are skeptical of its practical relevance: a common position is that this argument becomes secondary in explaining the appeal of reciprocal trade agreements once more realistic government objectives that include political concerns are acknowledged.

To answer our first question, we therefore construct a model in which governments are motivated by both political and terms-of-trade considerations. We show that more general government objectives do not overturn the view that trade agreements provide governments with an escape from a terms-of-trade driven Prisoners' Dilemma. Moreover, in the leading formulations of political economy, and indeed whenever government objectives can be represented as a function of national prices and the terms of trade, this is all that trade agreements do: political considerations play no role in explaining why governments seek reciprocal trade agreements. While political considerations surely affect the trade objectives that governments seek to achieve, it is the terms-of-trade externality that creates an inefficiency when policies are set unilaterally and that therefore explains why governments need a reciprocal trade agreement in order to accomplish their objectives. ${ }^{3}$

Having identified the inefficiency that reciprocal trade agreements are designed to eliminate, we turn next to the second question raised above: Why would it be mutually advantageous to form an agreement that calls for reciprocal tariff liberalization? At a general level, the answer to this question follows naturally from the answer to the first question: termsof-trade externalities lead governments to restrict trade more than is efficient, and so an efficiency-enhancing trade agreement naturally involves reciprocal tariff liberalization. We push this idea much further, however, and examine the actual representation of reciprocity found in GATT. Our framework provides a logic to this representation provided that, among those tariff

\footnotetext{
${ }^{2}$ More recently, this view has been explored in papers by Dixit (1987) and McMillan $(1986,1989)$.

${ }^{3}$ Political considerations might give rise to a separate motivation for reciprocal trade agreements if governments seek such agreements to gain commitment relative to their private sectors. This possibility is explored by Maggi and Rodriguez (1996) and Staiger (1995). It has not yet been demonstrated, however, that this hypothesis accounts for the principles of reciprocity and non-discrimination that form the pillars of GATT.
} 
combinations that achieve efficiency, governments seek through GATT to implement the tariffs that remain when terms-of-trade motivations are eliminated from each government's unilateral trade policy choices. In particular, we establish that an efficient trade agreement can be implemented under reciprocity only if the agreement is characterized by such tariffs.

We consider next the third question raised above: Is there an efficiency rationale for the principle of non-discrimination (MFN)? We find that a multilateral system built on the principle of reciprocity can implement an efficient agreement only if it also embraces the principle of non-discrimination. Hence, our framework provides a formal rationale for the linkage between the principles of reciprocity and non-discrimination as pillars of an efficient multilateral trading system. In essence, reciprocity and non-discrimination serve as principles that work together to deliver an efficient trade-policy outcome by eliminating the restrictions in trade that are associated with terms-of-trade motivations. To our knowledge, this result represents the first efficiency rationale for the principle of non-discrimination.

Finally, we consider the possibility of preferential agreements and re-phrase our fourth question in the more specific form: Can a multilateral system that relies on the principle of reciprocity to determine external tariffs implement an efficient agreement in the presence of freetrade agreements or customs unions? We find that the principle of reciprocity cannot serve to implement an efficient agreement when free trade areas are present. On the other hand, reciprocity may implement an efficient agreement in the presence of a customs union, but only if the union is comprised of similar countries (i.e., "natural integration partners"). These conditions are quite stringent, and so we offer only limited support for the hypothesis that the principle of reciprocity can deliver an efficient trade agreement in the presence of preferential trade agreements. Instead, our results offer support for the view that preferential agreements pose a threat to the existing multilateral system.

The intuition for our central conclusions derives from three basic insights. First, we establish that an efficient multilateral trade agreement can be implemented under GATT's principle of reciprocity provided that the externalities associated with trade intervention are transmitted only through world price movements. Second, we show that externalities indeed are transmitted only through world price movements when tariffs conform to MFN. Thus, the principles of reciprocity and MFN work hand-in-hand to facilitate the implementation of efficient trade arrangements. Finally, when tariffs are discriminatory, we find that externalities 
travel through both world and local prices. For a given aggregate volume of trade, an importing government that selects discriminatory tariffs prefers that a greater share of the import volume come from the foreign export partner on whom it places the highest tariff. Since foreign export volumes are in turn determined by foreign local prices, it follows that local prices transmit externalities as well when tariffs are discriminatory. Discriminatory tariffs, such as arise when countries form preferential agreements, thus tend to undermine reciprocity as a principle with which to implement efficient trade policies. ${ }^{4}$

To develop these points, we construct a simple model of trade between countries. In particular, we model trade in a partial-equilibrium framework, and we derive some of our more specific findings under the assumption that demand and supply functions take linear forms. The central conclusions of our analysis, however, are quite general. 5 We present our ideas in a simple model for two main reasons. First, the partial-equilibrium setting enables us to give a concrete interpretation of the respective roles of political and terms-of-trade motivations in the determination of trade policy. Second, working with this simple structure, we are able to obtain closed-form solutions for trade-policy choices, and this makes it possible to report as well some more specific findings. For example, we show that governments will subsidize exports, if the parameters associated with political motivations are large in magnitude. ${ }^{6}$

The remainder of the paper proceeds as follows. We present in Section II a model of trade between two countries. Here we identify the inefficiency associated with unilateral tariff setting that a reciprocal trade agreement can correct. In Section III, we define the principle of reciprocity and explore the sense in which this principle promotes efficient outcomes. Section IV extends our analysis to a many-country framework. In Section V, we make use of this extended framework and present our main results regarding the efficiency relationships between reciprocity, non-discrimination and preferential agreements. Section VI concludes.

\footnotetext{
${ }^{4}$ The only form of tariff discrimination that can be excepted from this statement amounts to the case where previously independent countries join together in complete political and economic union to become a "single country" for the purposes of trade policy.

${ }^{5}$ For example, we show in a separate paper (Bagwell and Staiger, 1996a) that our answer to the first question given above is very general: it holds for a general-equilibrium model of trade, provided only that government preferences can be represented as general functions of local and world prices. The present paper develops this point in a model for which political motivations can be given a concrete interpretation. In addition, we offer here answers to the other three questions mentioned above.

${ }^{6}$ As is usual, the partial-equilibrium analysis can be re-interpreted as a general-equilibrium model, if an additional numeraire good is included that consumers value in a quasi-linear fashion. With this modification, our modeling approach parallels the approach commonly developed in general-equilibrium models of trade policy (see, e.g., Grossman and Helpman, 1994). In the text, we develop this general-equilibrium interpretation of our analysis in a sequence of footnotes.
} 


\section{Reciprocal Trade Agreements in a Two-Country Framework}

In this section, we develop a simple two-country partial-equilibrium model. This model allows us to explore the notion of reciprocity without the need to consider the topic of nondiscrimination. The latter issue is addressed in the many-country model of Sections IV and V.

\section{A. Model}

We consider a world economy in which two countries - home (no*) and foreign $\left(^{*}\right)$ trade two goods $x$ and $y$, with $x(y)$ the natural import good of the home (foreign) country. In this subsection, we construct a simple model, characterize the market-clearing values for prices and quantities, and then express government objectives in terms of these values.

Basic Assumptions: We assume that each of the two goods is demanded in each country according to a symmetric demand function, $D$. Letting $p_{x}$ and $p_{y}$ denote the local prices of $\operatorname{good} x$ and $y$ in the domestic market, the domestic demand function for $\operatorname{good} i=\{x, y\}$ is represented by the decreasing function $D\left(p_{i}\right)$. Foreign demand functions are symmetrically represented in terms of the foreign local prices, $p_{x}^{*}$ and $p_{y}^{*}$. Each good is also produced in each country, and we allow that countries have different skills in this regard so that a basis for trade exists. The respective supply functions derive from competitive markets, and the domestic supply functions are represented by the increasing functions, $Q_{x}\left(p_{x}\right)$ and $Q_{y}\left(p_{y}\right)$. Similarly, the foreign supply functions are increasing and given as $Q_{x}^{*}\left(p_{x}^{*}\right)$ and $Q_{y}^{*}\left(p_{y}^{*}\right)$. Consistent with the hypothesis that the domestic country is the natural importer of good $x$, we assume that $Q_{x}(p)=$ $Q_{y}^{*}(p)<Q_{y}(p)=Q_{x}^{*}(p)$. Finally, the associated domestic and foreign profit functions are represented with the increasing functions, $\Pi_{x}\left(p_{x}\right), \Pi_{y}\left(p_{y}\right), \Pi_{x}^{*}\left(p_{x}^{*}\right)$ and $\Pi_{y}^{*}\left(p_{y}^{*}\right)$.

While these basic assumptions underlie the broad themes developed below, further insights can be gained when the functional forms are given additional structure. To this end, we assume that the demand and supply functions take simple linear forms: $D\left(p_{i}\right)=1-p_{i}$, $Q_{x}\left(p_{x}\right)=p_{x} / 2, Q_{y}\left(p_{y}\right)=p_{y}, Q_{x}^{*}\left(p_{x}^{*}\right)=p_{x}^{*}$, and $Q_{y}^{*}\left(p_{y}^{*}\right)=p_{y}^{*} / 2$. The profit functions are then given by $\Pi_{x}\left(p_{x}\right)=\left(p_{x}\right)^{2 / 4}, \Pi_{y}\left(p_{y}\right)=\left(p_{y}\right)^{2 / 2}, \Pi_{x}^{*}\left(p_{x}^{*}\right)=\left(p_{x}^{*}\right)^{2 / 2}$ and $\Pi_{y}^{*}\left(p_{y}^{*}\right)=\left(p_{y}^{*}\right)^{2 / 4} .^{7}$

\footnotetext{
${ }^{7}$ The domestic functions derive from production functions of the form $Q_{x}=\left(L_{x}\right)^{1 / 2}$ and $Q_{y}=\left(2 L_{y}\right)^{1 / 2}$, where $L x(L y)$ is the labor used in the production of good $x(y)$, under the assumption that labor supply is infinitely elastic at a unitary wage. Similar remarks apply for the foreign functions. The partial-equilibrium model can be closed with the addition of a traded numeraire good $z$, where the utility of a representative agent is given by $U=$ $C_{z}+\left(C_{x}-C_{x}^{2} / 2\right)+\left(C_{y}-C_{y}^{2} / 2\right)$ with $C_{z}$ and $C_{i}$ denoting consumption of the numeraire good $z$ and $\operatorname{good} i=\{x, y\}$. If $z$ is sufficiently abundant in each country so that it is always consumed in positive amounts by each agent, the
} 
Price Determination: To describe the determination of market prices, we first introduce some notation for tariffs. Let $\tau_{x}$ denote the (specific) import tariff applied by the domestic government to imports of good $x$, and let $\tau_{y}$ represent the (specific) export subsidy given by the domestic country to exports of good $y$. In similar fashion, we represent the foreign country's import tariff as $\tau_{y}^{*}$ and export subsidy as $\tau_{x}^{*}$.

Provided trade taxes do not prohibit all trade, local prices in each country must obey arbitrage and market-clearing conditions. These conditions are given respectively as follows:

$$
\begin{aligned}
& p_{i}=p_{i}^{*}+\tau_{i}-\tau_{i}^{*}, i=x, y \\
& Q_{i}\left(p_{i}\right)+Q_{i}^{*}\left(p_{i}^{*}\right)=D\left(p_{i}\right)+D\left(p_{i}^{*}\right), i=x, y .
\end{aligned}
$$

These two sets of equations yield market-clearing domestic prices, $p_{x}\left(\tau_{x}-\tau_{x}^{*}\right)$ and $p_{y}\left(\tau_{y}^{*}-\tau_{y}\right)$, as well as the associated foreign prices, $p_{x}^{*}\left(\tau_{x}-\tau_{x}^{*}\right)$ and $p_{y}^{*}\left(\tau_{y}^{*}-\tau_{y}\right)$. The market-clearing local prices depend upon trade policy only through the associated net tariffs, $\tau_{x}-\tau_{x}^{*}$ and $\tau_{y}^{*}-\tau_{y}$. Given that demand (supply) functions are downward (upward) sloping, it is direct to confirm that a higher net tariff raises (lowers) the local price in the importing (exporting) country.

Consider next the world (i.e., offshore) prices. Letting $p_{x}^{w}$ and $p_{y}^{w}$ denote the world price of goods $x$ and $y$, respectively, we have the following definition: $p_{i} \equiv p_{i}^{w}+\tau_{i}, i=x, y$. Having already solved for the market-clearing local prices, we may thus represent the marketclearing world prices as $p_{x}^{w}\left(\tau_{x}, \tau_{x}^{*}\right)$ and $p_{y}^{w}\left(\tau_{y}, \tau_{y}^{*}\right)$. Using the monotonicity of the demand and supply functions, it is direct to confirm that the world price is decreasing in each argument: The world price falls when the import tariff is raised and when the export subsidy is increased. 8 Finally, it is convenient to express market-clearing local prices as explicit functions of world prices: $\hat{p}_{i}\left(\tau_{i}, p_{i}^{w}\left(\tau_{i}, \tau_{i}^{*}\right)\right)=p_{i}^{w}\left(\tau_{i}, \tau_{i}^{*}\right)+\tau_{i}$ and $\hat{p}_{i}^{*}\left(\tau_{i}^{*}, p_{i}^{w}\left(\tau_{i}, \tau_{i}^{*}\right)\right)=p_{i}^{w}\left(\tau_{i}, \tau_{i}^{*}\right)+\tau_{i}^{*}$

Trade Volumes: We consider next the market-clearing import and export volumes. The domestic import volume for good $x$ is denoted by $M\left(\hat{p}_{x}\right) \equiv D\left(\hat{p}_{x}\right)-Q_{x}\left(\hat{p}_{x}\right)$, and the domestic export volume of good $y$ is represented by $E\left(\hat{p}_{y}\right) \equiv Q_{y}\left(\hat{p}_{y}\right)-D\left(\hat{p}_{y}\right)$. Using the linear structure of the model, it is straightforward to derive conditions under which the trade volume is positive:

marginal utility of income will be fixed at one and partial-equilibrium analysis of the two non-numeraire sectors is appropriate. Trade in the numeraire good is then determined by the requirement of overall trade balance.

${ }^{8}$ Formally, the world price function takes the form $p_{x}^{w}\left(\tau_{x}, \tau_{x}^{*}\right)=\left[4-4 \tau_{x}^{*}-3 \tau_{x}\right] / 7$ and $p_{y}^{w}\left(\tau_{y}, \tau_{y}^{*}\right)=\left[4-4 \tau_{y}-3 \tau_{y}^{*} / 7\right.$. The closed-form solutions for the market-clearing local prices now can be directly derived. 
(1). $\quad M\left(\hat{p}_{x}\right)>0$ iff $\tau_{x}-\tau_{x}^{*}<1 / 6 ; \quad E\left(\hat{p}_{y}\right)>0$ iff $\tau_{y}^{*}-\tau_{y}<1 / 6$

Thus, trade occurs so long as the net tariff is not too large. Foreign import and export volumes, $M^{*}\left(\hat{p}_{y}^{*}\right)$ and $E^{*}\left(\hat{p}_{x}^{*}\right)$, are defined symmetrically, with $M\left(\hat{p}_{x}\right)=E^{*}\left(\hat{p}_{x}^{*}\right)$ and $M^{*}\left(\hat{p}_{y}^{*}\right)=E\left(\hat{p}_{y}\right)$ then following directly from the market-clearing requirement.

Government Objectives: We are now prepared to define government welfare functions. Governments are assumed to maximize a weighted sum of consumer surplus, producer surplus and tariff revenue. Following Baldwin (1987), we allow for political-economy influences with the assumption that governments may weigh producer surplus differently than consumer surplus and tariff revenue. This representation has recently been given micro-analytic foundations in the explicit lobbying model developed by Grossman and Helpman (1994). ${ }^{9}$

Let $\gamma_{m} \geq 1\left(\gamma_{e} \geq 1\right)$ denote the weight that the government attaches to the producer surplus earned by import-competing (exporting) firms. The welfare that the domestic government experiences on its import and export goods is then defined as follows:

$$
\begin{aligned}
& W_{x}\left(\hat{p}_{x}, p_{x}^{w}\right) \equiv \int_{\hat{p}_{x}}^{l} D\left(p_{x}\right) d p_{x}+\gamma_{m} \Pi_{x}\left(\hat{p}_{x}\right)+\left[\hat{p}_{x}-p_{x}^{w}\right] M\left(\hat{p}_{x}\right) \\
& W_{y}\left(\hat{p}_{y}, p_{y}^{w}\right) \equiv \int_{\hat{p}_{y}}^{l} D\left(p_{y}\right) d p_{y}+\gamma_{e} \Pi_{y}\left(\hat{p}_{y}\right)-\left[\hat{p}_{y}-p_{y}^{w}\right] E\left(\hat{p}_{y}\right) .
\end{aligned}
$$

The domestic-government welfare function is then the sum of the welfare achieved on the import good and the export good: $W\left(\hat{p}_{x}, \hat{p}_{y}, p_{x}^{w}, p_{y}^{w}\right) \equiv W_{x}\left(\hat{p}_{x}, p_{x}^{w}\right)+W_{y}\left(\hat{p}_{y}, p_{y}^{w}\right) .10$ The foreigngovernment import and export welfare functions take analogous forms:

$$
\begin{aligned}
& W_{y}^{*}\left(\hat{p}_{y}^{*}, p_{y}^{w}\right) \equiv \int_{\hat{p}_{y}^{*}}^{l} D\left(p_{y}^{*}\right) d p_{y}^{*}+\gamma_{m} \Pi_{y}^{*}\left(\hat{p}_{y}^{*}\right)+\left[\hat{p}_{y}^{*}-p_{y}^{w}\right] M^{*}\left(\hat{p}_{y}^{*}\right) \\
& W_{x}^{*}\left(\hat{p}_{x}^{*}, p_{x}^{w}\right) \equiv \int_{\hat{p}_{x}^{*}} D\left(p_{x}^{*}\right) d p_{x}^{*}+\gamma_{e} \Pi_{x}^{*}\left(\hat{p}_{x}^{*}\right)-\left[\hat{p}_{x}^{*}-p_{x}^{w}\right] E^{*}\left(\hat{p}_{x}^{*}\right)
\end{aligned}
$$

so that $W^{*}\left(\hat{p}_{x}^{*}, \hat{p}_{y}^{*}, p_{x}^{w}, p_{y}^{w}\right) \equiv W_{y}^{*}\left(\hat{p}_{y}^{*}, p_{y}^{w}\right)+W_{x}^{*}\left(\hat{p}_{x}^{*}, p_{x}^{w}\right)$ defines the foreign welfare function.

\footnotetext{
${ }^{9}$ In Grossman and Helpman (1994), governments behave as if they place greater weight on the producer surplus of politically represented sectors provided that these sectors compose a small fraction of the overall economy.

${ }^{10}$ In the general equilibrium interpretation of our model presented in footnote 7 , the tariff-revenue term in the welfare functions corresponds to consumer surplus arising from the consumption of the numeraire good, $z$.
} 


\section{B . Nash Equilibria}

In this subsection, we consider a static tariff game, in which the domestic government unilaterally selects its tariff policy, $\left(\tau_{x}, \tau_{y}\right)$, in order to maximize its welfare, $W$, at the same time that the foreign government unilaterally chooses its tariff policy, $\left(\tau_{y}^{*}, \tau_{x}^{*}\right)$, in order to maximize its welfare, $W^{*}$. Our purpose is to characterize the Nash tariff policies, paying particular attention to the relation between Nash policies and the political-economy parameters.

We begin with a general characterization of the best-response tariff policies. To this end, we define the parameters,

$$
\begin{aligned}
& \lambda_{x} \equiv\left[\partial p_{x}^{w} / \partial \tau_{x}\right] /\left[d \hat{p}_{x} / d \tau_{x}\right]=\left[\partial p_{y}^{w} / \partial \tau_{y}^{*}\right] /\left[d \hat{p}_{y}^{*} / d \tau_{y}^{*}\right] \equiv \lambda_{y}^{*} \\
& \lambda_{y} \equiv\left[\partial p_{y}^{w} / \partial \tau_{y}\right] /\left[d \hat{p}_{y} / d \tau_{y}\right]=\left[\partial p_{x}^{w} / \partial \tau_{x}^{*}\right] /\left[d \hat{p}_{x}^{*} / d \tau_{x}^{*}\right] \equiv \lambda_{x}^{*}
\end{aligned}
$$

and then maximize $W$ with respect to $\left(\tau_{x}, \tau_{y}\right)$ and $W^{*}$ with respect to $\left(\tau_{y}^{*}, \tau_{x}^{*}\right)$. We find that the best-response tariffs for the domestic and foreign governments are defined implicitly by

$$
\text { Home: } \quad W_{\hat{p}_{x}}+\lambda_{x} W_{p_{x}^{w}}=0=W_{\hat{p}_{y}}+\lambda_{y} W_{p_{y}^{w}}
$$

Foreign: $\quad W_{\hat{p}_{y}^{*}}^{*}+\lambda_{y}^{*} W_{p_{y}^{w}}^{*}=0=W_{\hat{p}_{x}^{*}}^{*}+\lambda_{x}^{*} W_{p_{x}^{w}}^{*}$

The best-response tariffs are thus determined by the combined impact that the implied local and world price movements have on welfare.

A general interpretation can be offered with reference to Figure 1 . Let $A \equiv\left(\tau_{x}, \tau_{x}^{*}\right)$ represent an initial tariff pair for good $x$. This pair is associated with a domestic iso-local-price line (i.e., an iso-net-tariff line), denoted as $\iota(A) \rightarrow \iota(A)$, and an iso-world-price line, given as $p_{x}^{w}(A) \rightarrow p_{x}^{w}(A)$. The iso-local-price line is linear with a slope of unity, since the net tariff is held constant when an increase in the import tariff is matched by an equal increase in the export subsidy; on the other hand, the iso-world-price line slopes downward, because the world price can be held constant only if an increase in the export subsidy is balanced against a decrease in the import tariff. For a fixed $\tau_{x}^{*}$, when $\tau_{x}$ is increased to $\tau_{x}^{b}$, a new point $C \equiv\left(\tau_{x}^{l}, \tau_{x}^{*}\right)$ is induced. This point lies on new iso-price lines, represented as $u(C) \rightarrow u(C)$ and $p_{x}^{w}(C) \rightarrow p_{x}^{w}(C)$, and the local (world) price is now higher (lower) than it was originally at $A$.

As (2) suggests, the overall movement from $A$ to $C$ can be disentangled into separate movements in the world and local prices, respectively. The movement from $A$ to $B$ captures the 
induced reduction in the world price, holding fixed the local price, and the welfare implications of this change for the domestic government are associated in (2) with the term $W_{p x}$. Similarly, the movement from $B$ to $C$ isolates the local price change, with the corresponding welfare change for the domestic government captured in (2) with the term $W_{\hat{p}_{x}}$. The world-price movement from $A$ to $B$ illustrates the cost-shifting inefficiency that arises when policies are set unilaterally. If the domestic government aspires to a local price corresponding to the iso-localprice line $u(C) \rightarrow u(C)$, then a unilateral increase in the domestic import tariff passes some of the costs of this outcome to the foreign government, whose exports are sold at a lower world price.

We now exploit the specific structure of the model and offer further interpretation of the best-response tariffs. Best-response tariffs are determined by two forces: the impact of tariffs on world prices (the terms of trade) and the impact of tariffs on local prices. It is through the terms-of-trade effect associated with world price movements that a country can redistribute surplus from its trading partner to itself. As we demonstrate below, the local-price effect can be further disentangled into two component effects: a political-economy effect and an efficiency effect. The political-economy effect refers to the ability of trade policy to alter the local price and redistribute surplus between domestic producers and domestic consumers or tariff revenue, holding the volume of trade fixed. Trade policies also have an efficiency effect through their impact on local prices, as these local price changes alter the volume of trade and thereby affect welfare. We establish below that the terms-of-trade effect leads governments to restrict trade more than if each were motivated only by local price considerations.

To make these points, we note that the best-response condition (2) for the home government may be re-written as:

$$
\begin{aligned}
& \left\{Q_{x}\left(\hat{p}_{x}\right)\left[\gamma_{m}-1\right]+\tau_{x}\left[\partial M / \partial \hat{p}_{x}\right]\right\}+\left[3 M\left(\hat{p}_{x}\right) / 4\right]=0 \\
& \left\{Q_{y}\left(\hat{p}_{y}\right)\left[\gamma_{e}-1\right]-\tau_{y}\left[\partial E / \partial \hat{p}_{y}\right]\right\}+\left[-4 E\left(\hat{p}_{y}\right) / 3\right]=0
\end{aligned}
$$

where we use the fact that $\lambda_{x}=-3 / 4$ and $\lambda_{y}=-4 / 3$. The home import and export policies are optimal under (3a) and (3b), respectively. Similar conditions apply for the foreign government.

The terms in curly brackets on the LHS of (3a) correspond to $W_{\hat{p}_{x}}$ in (2) and represent the local-price effect of a small increase in the domestic import tariff, $\tau_{x}$. The first term, $Q_{x}\left(\hat{p}_{x}\right)\left[\gamma_{m}-1\right]$, measures the net effect on consumer surplus and import-competing producer surplus when the fixed $Q_{x}\left(\hat{p}_{x}\right)$ units of domestically produced and consumed $x$ are exchanged 
domestically at a higher price. ${ }^{11}$ This political-economy effect is positive when the implied redistribution is desirable (i.e., when $\gamma_{m}>1$ ). The second term, $\left.\tau_{x} / \partial M / \partial \hat{p}_{x}\right]$, is negative and captures the efficiency effect. It gives the efficiency cost to the domestic country when its import tariff is raised slightly, thereby inducing import volume (and tariff revenue) to fall. Finally, the last term on the LHS of (3a), given by $(3 / 4) M\left(\hat{p}_{x}\right)$, is positive and corresponds to $\lambda_{x} W_{p_{x}}^{w}$ in (2). It represents the increase in tariff revenue collected on the $M\left(\hat{p}_{x}\right)$ units of imported $x$ attributable to the reduction in the world price that follows a slight increase in the import tariff; this is the terms-of-trade effect, and it reflects a redistribution of surplus from foreign exporters to the domestic country, the effect of which is to lower the cost to the domestic government of providing additional protection to its import-competing producers. Condition (3b) admits a similar interpretation, except that the terms-of-trade effect associated with a small increase in the export subsidy now redistributes surplus from the home to the foreign country, the effect of which is to raise the cost to the domestic government of providing additional help to its export interests.

Letting $\tau_{x}^{R}\left(\tau_{x}^{*}\right)$ and $\tau_{y}^{R}\left(\tau_{y}^{*}\right)$ denote the home government's import-tariff and exportsubsidy best-response (i.e., reaction) curves, we next solve ( $3 a$ ) and ( $3 b$ ) to find that

$$
\tau_{x}^{R}\left(\tau_{x}^{*}\right)=\frac{\left[8 \gamma_{m}-5\right]+2 \tau_{x}^{*}\left[13-4 \gamma_{m}\right]}{4\left[17-2 \gamma_{m}\right]} ; \quad \tau_{y}^{R}\left(\tau_{y}^{*}\right)=\frac{4\left[3 \gamma_{e}-4\right]+3 \tau_{y}^{*}\left[11-3 \gamma_{e}\right]}{3\left[25-3 \gamma_{e}\right]} .
$$

The second-order conditions are satisfied if the political-economy weights are not too large, and so we assume that $\gamma_{m} \in[1,3]$ and $\gamma_{e} \in[1,3] .{ }^{12}$ The foreign-government import-tariff and export-subsidy reaction functions, $\tau_{y}^{* R}\left(\tau_{y}\right)$ and $\tau_{x}^{* R}\left(\tau_{x}\right)$, can be expressed analogously.

We next determine the import tariffs and export subsidies at which the reaction curves intersect. Given the symmetry across countries and products, such a Nash equilibrium will be described by a Nash import tariff, $\tau_{m}^{N} \equiv \tau_{x}^{N}=\tau_{y}^{*}$, and a Nash export subsidy, $\tau_{e}^{N} \equiv \tau_{y}^{N}=\tau_{x}^{*}$. Solving, we find that the import-tariff and export-subsidy reaction curves agree if and only if

\footnotetext{
${ }^{11}$ The given $M\left(\hat{p}_{x}\right)$ units of imports also trade at a higher local price; however, the associated gain to total revenue is exactly offset by the corresponding loss to consumer surplus.

${ }^{12}$ The reaction curves are upward sloping. Intuitively, when the foreign export subsidy increases, the domestic country experiences a rise in imports (i.e., $M\left(\hat{p}_{x}\right)$ increases) and a fall in domestic production (i.e., $Q_{x}\left(\hat{p}_{x}\right)$ decreases). The former (latter) change magnifies (weakens) the terms-of-trade (political-economy) gain that is associated with a higher import tariff. Our finding that the best-response functions are increasing indicates that the magnification of the terms-of-trade effect dominates the weakening of the political-economy effect.
} 
(4). $\quad \tau_{m}^{N}=\frac{104 \gamma_{m}+51 \gamma_{e}-24 \gamma_{m} \gamma_{e}-113}{6\left[101-8 \gamma_{m}-9 \gamma_{e}\right]} ; \quad \tau_{e}^{N}=\frac{123 \gamma_{e}+56 \gamma_{m}-24 \gamma_{m} \gamma_{e}-179}{6\left[101-8 \gamma_{m}-9 \gamma_{e}\right]}$

Applying the conditions for prohibitive trade taxes recorded in (1) above, a positive trade volume occurs at the Nash tariffs if and only if $1 / 6>\tau_{m}^{N}-\tau_{e}^{N}$, which in turn is true if and only if (5). $5 / 8+9 \gamma_{e} / 8>\gamma_{m}$.

Thus, provided that the political significance of the import sector is not too large relative to that of the export sector, a Nash equilibrium with positive trade volume exists. Henceforth, we assume that (5) is satisfied. Figure 2 illustrates the Nash equilibrium and the reaction curves.

It is of interest to know whether the Nash import tariff and export subsidy are positive. We begin with the Nash import tariff. It is a simple matter to confirm that this tariff is positive over the relevant range of parameters, since it is in fact positive over an even larger set:

(6). $\quad \tau_{m}^{N}>0$ for all $\gamma_{m} \in[1,3]$ and $\gamma_{e} \in[1,3]$.

Without political-economy effects (i.e., when $\gamma_{m}=\gamma_{e}=1$ ), a government finds a slight import tariff desirable, since the first-order terms-of-trade benefit outweighs the second-order efficiency cost of a reduction in import volume. A reinforcing effect arises when political economy is present, as the political-economy effect associated with the redistribution of surplus to import-competing firms advances the case for an import tariff further.

The situation is more ambiguous with respect to the Nash export subsidy. We find that (7). $\quad \tau_{e}^{N}>0$ iff $\gamma_{m}>\left[1253-861 \gamma_{e}\right] /\left[56\left(7-3 \gamma_{e}\right)\right]$

To interpret this condition, consider the case in which the political-economy effect is absent. In this case, the condition in (7) is violated, and the standard prescription of an export tax emerges: a slight export tariff offers a first-order benefit that is associated with the terms-of-trade effect, while the efficiency cost of reduced trade volume is second order for a small export tariff. When political-economy effects are included, however, the attractiveness of an export tariff is reduced, since an additional political-economy cost is experienced, as surplus is redistributed from domestic exporters to domestic consumers and tariff revenue. When political-economy 
influences are sufficiently pronounced, a slight export tariff is no longer desirable. In fact, the Nash equilibrium then entails an export subsidy. ${ }^{13}$

These conclusions are illustrated in Figure 3. The upward-sloping line represents (5) and gives parameter combinations above which the Nash equilibrium net tariff exceeds the critical value of 1/6; for this range of parameters, a Nash equilibrium with positive trade volume does not exist. The export-subsidy inequality given in (7) is represented by the downwardsloping line. The Nash export subsidy is positive if the political-economy weights, $\gamma_{m}$ and $\gamma_{e}$, are sufficiently large. The Nash import tariff is positive throughout the parameter space.

Finally, we return to Figure 2 and explore the possibility of autarky Nash equilibria. The dotted line is a "no-trade" line, along which the net tariff achieves the critical value of 1/6. It is now easy to argue that all tariff/subsidy combinations to the northwest of the point $A B$ represent autarky equilibria. To see this, suppose that the trade-policy choices in good $x$ place the countries in this region, and consider the options available to the domestic government. Holding fixed the foreign-country export policy, if the domestic government is to deviate and induce a positive volume of trade, then it must cut its import tariff substantially and create a net tariff that lies below the no-trade line. But such an outcome is worse for the domestic government than is point $A$, which itself gives the autarky outcome. ${ }^{14}$ Thus, the domestic government cannot benefit by deviating, and the autarky trade policy is an equilibrium policy.

We summarize our specific findings with the following proposition:

\section{Proposition 1: In the static tariff game:}

(i). There exists a unique Nash equilibrium with positive trade volume.

(ii). In the Nash equilibrium with positive trade volume, the Nash import tariff is positive, but the Nash export subsidy is positive if and only if the political-economy parameters are sufficiently large in magnitude.

(iii). There also exist a continuum of autarky Nash equilibria.

\section{Reciprocal Trade Agreements}

In this subsection, we characterize the reciprocal trade agreement that is efficient from the governments' perspective, and we show that the Nash equilibrium is inefficient. We then

\footnotetext{
${ }^{13}$ Grossman and Helpman (1995) also note that an export subsidy is possible in a Nash equilibrium when the export sector has significant political power.

${ }^{14}$ It can be shown that welfare for a government declines along its reaction curve as the policy of its trading partner becomes more restrictive.
} 
define politically optimal tariffs as the tariffs that would be chosen by governments were they not motivated by their ability to affect the terms of trade. We find that a reciprocal trade agreement that implements such tariffs is efficient. Finally, we exploit the specific structure of our model in order to gain more insight into the role of political-economy parameters in the determination of the various tariff policies.

An efficient trade agreement calls for trade policies that maximize joint welfare, $W+W^{*}$. A first observation is that joint welfare is a function only of the net tariff levels. To see this, notice from the definitions of $W$ and $W^{*}$ that their sum is independent of world prices (since market clearing requires that $M\left(\hat{p}_{x}\right)=E^{*}\left(\hat{p}_{x}^{*}\right)$ and $\left.E\left(\hat{p}_{y}\right)=M^{*}\left(\hat{p}_{y}^{*}\right)\right)$. Intuitively, a change in world prices holding fixed local prices simply redistributes income across countries, and in our partial-equilibrium setting such a redistribution does not affect joint welfare, since the marginal utility of income for each country is fixed at unity. It follows that only local prices matter for efficiency. But, as we have seen, local prices depend only upon the net trade impediments in each sector, and so joint welfare is entirely determined by net tariffs.

Given the symmetry between sectors $x$ and $y$, the efficient net tariff for market $x$ will be the same as that for market $y$. Consequently, we may define $\iota \equiv \tau_{x}-\tau_{x}^{*} \equiv \tau_{y}^{*} \tau_{y}$ and characterize the efficient level of the net trade impediment, $\iota$. Letting $J(\iota) \equiv W+W^{*}$ denote joint welfare, and noting that the second-order condition, $J^{\prime \prime}(\iota)<0$, holds generally under our parameter restrictions, the first-order condition that $J^{\prime}(\iota)=O$ defines the efficient trade agreement, $\iota^{E}$. This first-order condition for efficiency can be written as

(8). $\quad W_{\hat{p}_{x}}+W_{\hat{p}_{x}^{*}}^{*} / \lambda_{x}^{*}=0$.

Condition (8) may be contrasted with those in (2) that describe the Nash equilibrium policies. Observe in particular that terms-of-trade effects are relevant for governments when setting their Nash policies, but terms-of-trade effects are not relevant for governments when setting efficient trade policies. This discrepancy indicates that Nash tariffs are not efficient.

We consider next politically optimal tariffs. These are the tariffs that governments would choose were they not motivated by the terms-of-trade consequences of their choices. Formally, politically optimal tariffs are defined as tariffs that satisfy

(9). $\quad W_{\hat{p}_{x}}=0=W_{\hat{p}_{y}} ; \quad W_{\hat{p}_{y}^{*}}^{*}=0=W_{\hat{p}_{x}^{*}}^{*}$ 
It is immediate from a comparison of (2), (8) and (9) that politically optimal tariffs are efficient and that these efficient tariffs will be attained if the terms-of-trade motivations from each government's Nash trade policy choices are eliminated.

A general perspective on these observations is possible with reference to Figure 1. If the domestic government seeks to achieve a local price that corresponds to the iso-local-price line $u(C) \rightarrow u(C)$, then the attainment of this price involves no world price externality when the domestic government's higher import tariff is balanced against a lower export subsidy, so that the world price is not altered. This corresponds to the movement from $A$ to $D$. When the domestic government is not motivated by the terms-of-trade implications of its tariff policy, it prefers choosing a higher tariff and inducing point $C$ instead of selecting a lower tariff and inducing point $A$ if and only if it also prefers point $D$ to point $A$. If both governments choose tariffs in this fashion, then a resulting consistent set of tariffs is politically optimal. In this case, the tariffs that governments select are not influenced by cost-shifting motivations, and so politically optimal tariffs are efficient. 15

On the other hand, when the domestic government chooses its import tariff mindful of the terms-of-trade externality associated with movements in the world price (i.e., the movement from $A$ to $B$ ), then it recognizes that some of the costs of achieving the higher domestic local price are shifted to the foreign government through the resulting reduction in the world price. As a consequence, the domestic government can be expected to choose higher import tariffs (i.e., restrict trade more) than is jointly efficient. This explains why Nash trade policies are always inefficient, with trade volumes that are too low. The broad conclusion that thus emerges is that an inefficiency arises when governments set trade policies unilaterally if and only if they are motivated by terms-of-trade considerations.

To confirm and extend these observations, we now exploit the specific structure of our model. We begin with politically optimal trade policies. Imposing symmetry and solving (9) for an import tariff and export subsidy, $\tau_{m}^{P O}$ and $\tau_{e}^{P O}$, that generate the local prices for each good that each government would prefer once terms-of-trade motivations have been eliminated, we find that

\footnotetext{
15 While a willingness to move from point $A$ to point $D$ in Figure 1 induces no externality through the terms of trade, it will involve a change in the foreign local price; however, if the foreign government also selects tariffs that are politically optimal, then a small change in the foreign local price will not alter the foreign welfare in a first-order sense.
} 


$$
\tau_{m}^{P O}=\frac{4\left(\gamma_{m}-1\right)\left(3-\gamma_{e}\right)}{59-8 \gamma_{m}-9 \gamma_{e}} \geq 0 ; \quad \tau_{e}^{P O}=\frac{4\left(\gamma_{e}-1\right)\left(4-\gamma_{m}\right)}{59-8 \gamma_{m}-9 \gamma_{e}} \geq 0
$$

Observe that the politically optimal trade policy calls for free trade when political-economy influences are absent. Otherwise, the politically optimal trade policy involves an import tariff and an export subsidy.

We consider next the net tariffs. The efficient net tariff solves (8), and it is given by $\iota^{E}$ $=4\left[2 \gamma_{m}-3 \gamma_{e}+1\right] /\left[59-8 \gamma_{m}-9 \gamma_{e}\right]$. Next, using (4), the Nash net tariff, $\iota^{N} \equiv \tau_{m}^{N}-\tau_{e}^{N}$, can be written as $\iota^{N}=\left[8 \gamma_{m}-12 \gamma_{e}+11\right] /\left[101-8 \gamma_{m}-9 \gamma_{e}\right]$. As expected, when political-economy effects are absent, the efficient net tariff corresponds to free trade and the Nash net tariff is positive. We may define the politically optimal net tariff as $\iota^{P O} \equiv \tau_{m}^{P O}-\tau_{e}^{P O}$. The politically optimal net tariff is indeed efficient, as it follows easily that $\iota^{P O}=\iota^{E}$. Finally, using (5) it can be shown that

$$
\iota^{N}-\iota^{E}=\frac{49\left[5-8 \gamma_{m}+9 \gamma_{e}\right]}{\left[101-8 \gamma_{m}-9 \gamma_{e}\right]\left[59-8 \gamma_{m}-9 \gamma_{e}\right]}>0
$$

Thus, whether or not political-economy effects are present, the Nash equilibrium is inefficient, and the inefficiency always takes the form of a trade volume that is too low. ${ }^{16}$

The central findings of this subsection are summarized as follows:

\section{Proposition 2: In the static tariff game:}

(i). The politically optimal import tariff and export subsidy are non-negative.

(ii). The politically-optimal trade policy is efficient.

(iii). The Nash trade policy is not efficient, as the net Nash tariff is too high and the Nash trading volume is too low.

\section{Reciprocity}

At this point, we have constructed a framework that reveals several specific insights regarding trade policy and that also delivers an answer to our first question. In particular, we find that governments can mutually gain from a reciprocal trade agreement if and only if their

\footnotetext{
${ }^{16}$ It is interesting to note that $\left.d \iota^{N}-\iota{ }^{E}\right) d \gamma_{m}<0<d\left(\iota^{N}-E^{E}\right) d \gamma_{e}$. Hence, while trade liberalization under an efficient trade agreement simply eliminates the terms-of-trade driven restrictions that arise in the absence of such an agreement, the magnitude of this liberalization is smaller (greater) as the political weight placed by govermments on import interests (export interests) is larger. This reflects the fact that a larger political weight on import interests (export interests) results in a lower (higher) trade volume in the Nash equilibrium, and thus a diminished (expanded) role for terms-of-trade considerations in the Nash trade policy choices.
} 
unilateral trade policies are motivated by their ability to affect the terms of trade. We now turn to our second question and explore the sense in which a reciprocal trade agreement that is founded on the principle of reciprocity can guide governments from their inefficient unilateral policies to the efficiency frontier.

To begin, it is useful to remark that the principle of reciprocity has (at least) two meanings. At a general level, the principle refers to the "balance of concessions" that governments seek when they enter into trade negotiations. As Dam (1970, p. 59) explains, the language of Article XXVIII bis, under which the rounds of GATT tariff negotiations occur, makes it clear that participation in these negotiations is to be voluntary, that negotiations are to be carried out "on a reciprocal and mutually advantageous basis," and that they are to be "conducted on a basis which affords adequate opportunity to take into account...the needs of individual contracting parties and individual industries...and...all other relevant circumstances including fiscal, developmental, strategic and other needs of the contracting parties concerned." Dam continues:

"This permissive approach to the content of tariff agreements is often referred to under the heading of reciprocity. From the formal legal principle that a country need make concessions only when other contracting parties offer reciprocal concessions considered to be 'mutually advantageous' has been derived the informal principle that exchanges of concessions must entail reciprocity." (Dam, 1970, p. 59)

As is evident from Dam's discussion, there is nothing in GATT which requires that the outcome of negotiations produce a balance of concessions. Indeed, the notion of a balance of concessions is no where defined in GATT. This general principle of reciprocity describes instead the broad manner in which governments seem to approach trade agreements.

On the other hand, under Article XXVIII, GATT provides for countries to renegotiate tariff commitments made initially under Article XXVIII bis, and it is when countries fail to come to agreement under these renegotiations that GATT imposes the requirement of reciprocity on the resulting tariff changes. In particular, if a country withdraws a tariff concession to which it had committed in a previous round of tariff negotiations, its trading partners are then authorized to withdraw "substantially equivalent concessions." We develop more fully and analyze these two notions of reciprocity below. 


\section{A. General Meaning}

We start with the general notion of reciprocity. In light of the balance of concessions that governments seek in the name of reciprocity it is widely held that enthusiasm for reciprocal trade agreements is a practice rooted in a mercantilist perspective. For example, Krugman (1991, p.25) observes:

To make sense of international trade negotiations, one needs to remember three simple rules about the objectives of the negotiating countries:

1). Exports are good.

2). Imports are bad.

3). Other things equal, an equal increase in imports and exports is good.

In other words, GATT-think is enlightened mercantilism.

Our first task is to establish that the mercantilist approach to reciprocal trade liberalization that seems to drive actual negotiations can be explained within our framework.

To make this point, we must formalize what is meant by a balance of concessions. As mentioned, this general notion, which is embodied in Krugman's third rule and which Bhagwati (1991) calls "first-difference reciprocity," is not defined in GATT, but we will say that a proposed set of reciprocal tariff reductions constitutes a balance of concessions provided that, when valued at existing world prices, the proposed set of tariff reductions together bring about equal increases in the volume of each country's imports and exports. ${ }^{17}$ Within the context of our model, we find that a proposed set of tariff $\left\{\tau_{x}^{l}, \tau_{y}^{d}, \tau_{x}^{*}, \tau_{y}^{*}\right\}$ will achieve a balance of concessions relative to an existing set of tariffs $\left\{\tau_{x}^{0}, \tau_{y}^{0}, \tau_{x}^{*}, \tau_{y}^{*_{0}}\right\}$ provided that $^{18}$

$$
\left[p_{x}^{w}\left(\tau_{x}^{0}, \tau_{x}^{* 0}\right)-p_{x}^{w}\left(\tau_{x}^{I}, \tau_{x}^{* I}\right)\right] M\left(\iota_{x}^{I}\right)=\left[p_{y}^{w}\left(\tau_{y}^{0}, \tau_{y}^{* 0}\right)-p_{y}^{w}\left(\tau_{y}^{l}, \tau_{y}^{*} I\right)\right] M^{*}\left(\iota_{y}^{l}\right),
$$

where we now simplify our notation and express import volumes directly as functions of net tariffs. By inspection of the welfare functions, it can be seen that this condition is satisfied by any set of tariff reductions that (i). leaves world prices unchanged, or (ii). alters world prices

${ }^{17}$ See Dam (1970, pp. 58-61) for a discussion and interpretation of the notion of reciprocity that appears in GATT negotiation rounds and that is broadly consistent with our approach.

18 Referring to the general-equilibrium interpretation of our model described in footnote 7 , we define reciprocity as the condition:

$$
p_{x}^{w}\left(\tau_{x}^{o}, \tau_{x}^{* o}\right)\left[M\left(\tau_{x}^{l}\right)-M\left(\tau_{x}^{o}\right)\right]+M_{z}\left(\tau_{x}^{l}, \tau_{y}^{l}\right)-M_{z}\left(\tau_{x}^{o}, \tau_{y}^{o}\right)=p_{y}^{w}\left(\tau_{y}^{o}, \tau_{y}^{* o}\right)\left[M^{*}\left(\tau_{y}^{l}\right)-M^{*}\left(\tau_{y}^{o}\right)\right]
$$

where $M_{z}$ denotes domestic-country imports of the numeraire good $z$. We utilize the requirement of balanced trade at the existing set of world prices to eliminate all existing trade volumes (i.e., the trade volumes at the existing set of tariffs) from this condition, while the requirement of balanced trade at the set of world prices under the proposed tariffs is used to eliminate trade in the numeraire good under the proposed tariffs from this condition. With this, the reciprocity condition takes the form given in the text. 
in a way that keeps each government's welfare unaffected by the world price changes. Hence, in seeking a balance of concessions, governments seek reciprocal tariff reductions from their trading partners that will neutralize the world-price effects of their own liberalization.

With a balance of concessions now defined, we examine the liberalization paths that governments might follow in moving from the Nash equilibrium to an efficient trade agreement. Given the symmetry of the model, it is natural to consider the class of symmetric liberalization paths along which $\tau_{x}=\tau_{y}^{*} \equiv \tau_{m}$ and $\tau_{y}=\tau_{x}^{*} \equiv \tau_{e}$. An important point is that any liberalization path within this class delivers the balance of concessions demanded under reciprocity. To see this, note that import volume may be written as $M(\iota) \equiv(1-6 \iota) / 7 \equiv M^{*}(\iota)$, where $\iota \equiv \tau_{m}-\tau_{e}$, while world prices satisfy $p_{x}^{w}\left(\tau_{m}, \tau_{e}\right) \equiv p_{y}^{w}\left(\tau_{m}, \tau_{e}\right)$. Thus, as liberalization occurs from the Nash equilibrium and the net tariff $\mathrm{t}$ is reduced, import and export volumes increase in equal amounts and the world prices adjust (if at all) in equal amounts as well.

The liberalization process can be further understood with reference to Figure 4. There, we depict Nash trade policies $\left(\tau_{m}^{N}, \tau_{e}^{N}\right)$ by the point labeled $N$ and politically optimal trade policies $\left(\tau_{m}^{P O}, \tau_{e}^{P O}\right)$ by the point labeled $P O$ under the assumption that export interests are sufficiently powerful to secure an export subsidy in the Nash equilibrium. ${ }^{19}$ Figure 4 also depicts iso-efficiency loci through both the Nash and politically optimal points. Each isoefficiency locus gives combinations of $\tau_{m}$ and $\tau_{e}$ that hold $\iota$ - and thus joint welfare $J\left(\iota \equiv \tau_{m}-\tau_{e}\right)$ - constant. We label the iso-efficiency line through $P O(N)$ by $\iota^{E} \rightarrow \iota^{E}\left(\iota^{N} \rightarrow \iota^{N}\right)$.

Starting from the Nash equilibrium, an efficient symmetric reciprocal trade agreement will call for the symmetric liberalization of net trade impediments (a reduction in $\iota$ ) in order to move the world from point $N$ in Figure 4 to a point (any point) on the iso-efficiency line $\iota^{E} \rightarrow \iota^{E} .20$ It is direct from the definition of $\iota^{E}$ and the concavity of $J(\iota)$ that joint welfare (and the welfare of each government) increases monotonically from the Nash equilibrium as $\iota$ falls to $\iota^{E}$. This liberalization process achieves Pareto improvements by "undoing" the effects of the termsof-trade motivations that caused the initial discrepancy between the Nash and efficient policies.

\footnotetext{
${ }^{19}$ It can be shown that the Nash import tariff (export subsidy) is greater (less) than the politically optimal import tariff (export subsidy). This relationship is illustrated in Figure 4.

${ }^{20}$ Symmetry across countries, products and trade policies ensures that movements along the iso-efficiency line, which by definition hold fixed the local prices in each country, will alter world prices in such a way as to leave each government's overall welfare unchanged.
} 
Thus, consistent with Krugman's (1991) three rules of "enlightened mercantilism," we find that: (1). Governments enter into negotiations seeking more open export markets ("exports are good"), because gaining market access abroad represents a less costly way to help export interests than a unilateral increase in the export subsidy above the best-response value (which would result in a terms-of-trade loss); (2). Import liberalization is viewed by governments as a concession ("imports are bad"), because it implies reducing the import tariff below the best-response value (and giving up the associated terms-of-trade benefits); and (3). Each government benefits from a concession at home that is balanced against an "equivalent" concession abroad ("other things equal, an equal increase in imports and exports is good"), because the balance of concessions so achieved serves to neutralize the terms-of-trade decline that would have made unilateral liberalization undesirable. The mercantilist nature of international trade negotiations is therefore readily explained within our framework. The explanation for this behavior reflects the desire of governments, whatever their political preferences, to escape from a terms-of-trade driven Prisoners' Dilemma.

\section{B . Article XXVIII}

We consider next the specific representation of reciprocity that is found within GATT. As discussed above, while reciprocity may be a desired outcome of negotiators, GATT does not require reciprocity in negotiating rounds (GATT Article XXVIII bis; Dam, 1970, pp. 58-59; Jackson, 1989, p. 123). However, once negotiations are concluded and tariff bindings are set, GATT does limit countries to abide by reciprocity in the event that a country withdraws or modifies a previously negotiated concession (tariff binding), which it is essentially free to do at any time (GATT Article XXVIII; Dam, 1970, pp. 79-99; Jackson, 1989, p. 119). Hence, rather than a requirement that the outcomes of negotiations conform to reciprocity, GATT imposes reciprocity in a more indirect way: Whatever the outcome of negotiations, any country is permitted to raise its tariffs in the future and thereby reduce import volumes, in the knowledge that its trading partners will be entitled to respond by withdrawing substantially equivalent concessions of their own. 21 An important issue is whether GATT's embodiment of reciprocity restricts the kinds of trade agreements that can be implemented.

\footnotetext{
$2{ }^{1}$ Article XXVIII renegotiations require that the negotiating parties "endeavor to maintain a general level of reciprocal and mutually advantageous concessions not less favorable to trade than that provided for in this Agreement." (GATT Article XXVIII:2) However, Article XXVIII renegotiations need not result in agreement, in which case "...the applicant is free to carry out the proposed changes. Both negotiating and consulted
} 
To explore this issue, we must formalize what is meant by substantially equivalent concessions. As with the notion of balanced concessions, GATT does not provide a precise definition of substantially equivalent concessions for the purpose of withdrawal, but we will say that, if a country proposes to increase a previously negotiated tariff, a proposed set of tariff increases by its trading partner will constitute a withdrawal of substantially equivalent concessions provided that, when evaluated at the original world prices, the proposed tariff increases together bring about equal reductions in the volume of each country's imports and

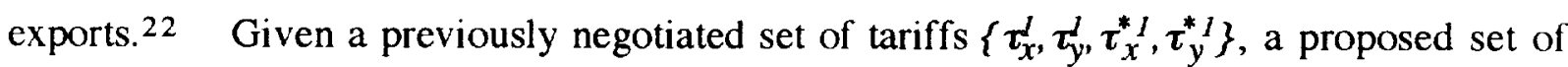
renegotiated tariffs $\left\{\tau_{x}^{2}, \tau_{y}^{2}, \tau_{x}^{* 2}, \tau_{y}^{*}\right\}$ will represent an initial tariff withdrawal by one country and a withdrawal of substantially equivalent concessions by its trading partner provided that

$$
\left[p_{x}^{w}\left(\tau_{x}^{l}, \tau_{x}^{* 1}\right)-p_{x}^{w}\left(\tau_{x}^{2}, \tau_{x}^{* 2}\right)\right] M\left(\iota_{x}^{2}\right)=\left[p_{y}^{w}\left(\tau_{y}^{l}, \tau_{y}^{* 1}\right)-p_{y}^{w}\left(\tau_{y}^{2}, \tau_{y}^{* 2}\right)\right] M^{*}\left(\iota_{y}^{2}\right)
$$

Once again, inspection of the welfare functions reveals that this condition is satisfied by any set of tariff increases that (i). leaves world prices unchanged, or (ii). alters world prices in a way that keeps each government's welfare unaffected by the world price changes. Thus, reciprocity ensures that any renegotiation will be over the set of outcomes which are feasible under the world prices that were established in the original negotiations.

Effectively, then, the representation of reciprocity in GATT implies that, when governments negotiate tariff bindings, they are really negotiating a set of world prices upon which, in the event of future tariff increases by any one country, reciprocal tariff increases by its trading partners will be gauged. We formalize this representation of reciprocity in the following Bilateral Negotiation Game applied to each good:

Stage 1: $\quad$ Governments bargain over the world price.

Stage 2: $\quad$ Each government announces a tariff pair consisting of a tariff level for itself and that implied for its trading partner by the world price from stage 1 .

Stage 3: If each government announces the same tariff pair in stage 2, then this tariff pair is implemented as the outcome of the negotiation. If governments announce different tariff pairs in stage 2 , then the mostrestrictive tariff pair is implemented.

contracting partners are correspondingly free to withdraw 'substantially equivalent concessions.'" (Dam, 1970, p.86).

${ }^{22}$ Dam (1970, pp. 87-91) provides an interpretation of GATT's definition of substantially equivalent concessions that is broadly consistent with our approach. 
This game allows each government to "renegotiate" to a new trade-policy pair, provided that the pair generates the same world price that arose in the first stage. ${ }^{23}$ As our interest lies in the set of trade policy outcomes that can be achieved under the representation of reciprocity given in stages 2 and 3, we do not offer a formal description of the stage-1 bargaining process. ${ }^{24}$

In light of the symmetry of the model, we again consider the class of symmetric tariffs $\left(\tau_{x}=\tau_{y}^{*} \equiv \tau_{m}\right.$ and $\left.\tau_{y}=\tau_{x}^{*} \equiv \tau_{e}\right)$ and the corresponding symmetric world price $\left(p_{x}^{w}=p_{y}^{w} \equiv p^{w}\right)$. We will say that a tariff pair $\left\{\overline{\boldsymbol{\tau}}_{m}, \overline{\boldsymbol{\tau}}_{e}\right\}$ can be implemented under reciprocity if there exists a $\bar{p}^{w}$ such that any Nash equilibrium of the subgame corresponding to stages 2 and 3 of the Bilateral Negotiation Game yields the outcome $\left\{\overline{\boldsymbol{\tau}}_{m}, \overline{\boldsymbol{\tau}}_{e}\right\}$ when $\bar{p}^{w}$ is selected in stage 1.

We first state a property of any tariff pair that can be implemented under reciprocity:

Proposition 3: A tariff pair can be implemented under reciprocity if and only if it satisfies either $\left\{W_{\hat{p} x}=0, W_{\hat{p}_{y}^{*}}^{*}=0, W_{\hat{p}_{x}^{*}}^{*} \geq 0, W_{\hat{p}_{y}} \geq 0\right\}$ or $\left\{W_{\hat{p}_{y}}=0, W_{\hat{p}_{x}^{*}}^{*}=0, W_{\hat{p}_{y}^{*}}^{*} \leq 0, W_{\hat{p}_{x}} \leq 0\right\}$.

Proof: The government that announces the binding (i.e., most-restrictive) tariff pair in stage 2 must select the tariff pair that maximizes the value of its objectives given the world price determined in stage 1. Thus, if $\left\{\overline{\boldsymbol{\tau}}_{m}, \overline{\boldsymbol{\tau}}_{e}\right\}$ corresponds to the importing (exporting) government's announced tariff pair, then (i). $\left\{\overline{\boldsymbol{\tau}}_{m}, \overline{\boldsymbol{\tau}}_{e}\right\}$ must satisfy $W_{\hat{p}_{x}}=0=W_{\hat{p}_{y}^{*}}^{*}\left(W_{\hat{p}_{y}}=0\right.$ $\left.=W_{\hat{P}_{x}^{*}}^{*}\right)$, and (ii). $\left\{\overline{\boldsymbol{\tau}}_{m}, \overline{\boldsymbol{\tau}}_{e}\right\}$ must be no less restrictive than the exporting (importing) government's announced tariff pair, implying that $\left\{\overline{\boldsymbol{\tau}}_{m}, \overline{\boldsymbol{\tau}}_{\boldsymbol{e}}\right\}$ must satisfy $\boldsymbol{W}_{\hat{p}_{x}^{*}}^{*} \geq 0$ and $\boldsymbol{W}_{\hat{p}_{y}} \geq 0$ $\left(W_{\hat{p}_{y}^{*}}^{*} \leq 0\right.$ and $\left.W_{\hat{p}_{x}} \leq 0\right)$ as well. $\boldsymbol{Q} \cdot \boldsymbol{E} . \boldsymbol{D}$.

\footnotetext{
${ }^{23}$ By the most-restrictive tariff pair, we mean the tariff pair that leads to the least trade volume. In specifying the Bilateral Negotiation Game, we restrict attention to tariff renegotiations that satisfy the definition of reciprocity by keeping the world price fixed. This involves no formal loss of generality. Consider any tariff pair A consistent with the definition of reciprocity that a government might announce that induces a different world price. Then there exists another tariff pair $B$ that induces the same local price and preserves the original world price. The two tariff pairs induce the same trade volumes and the same government welfares, and so the government would achieve the same welfare outcome by announcing tariff pair B instead of tariff pair $A$.

${ }^{24} \mathrm{We}$ think of Stage 1 of the Bilateral Negotiation Game as representing a round of tariff negotiations under Article XXVIII bis, and Stage 2 as the ensuing Article XXVIII renegotiation. Note that nothing "happens" between stages one and two (i.e., no "shock," no new information), and that this is consistent with the fact that no justification need be given for renegotiation under Article XXVIII. GATT also provides for the temporary suspension of tariff commitments under Article XIX, and authorizes trading partners to temporarily suspend "substantially equivalent concessions" of their own. However, unlike Article XXVIII, recourse to Article XIX requires that a country establish injury as a result of "unforeseen developments" in the presence of the concession it seeks to suspend (Dam, 1970, p. 101).
} 
Proposition 3 says that a tariff pair can be implemented under reciprocity if and only if, when faced with the fixed world prices implied by that tariff pair, at least one government is content with the volume of trade and no government wants reduced trade volume.

We are now prepared to determine whether efficient trade agreements can be implemented under reciprocity, and if so, the form that these agreements take. Our results are contained in the next proposition:

Proposition 4: An efficient trade agreement can be implemented under reciprocity if and only it is characterized by tariffs which are set at their politically optimal levels.

Proof: An efficient agreement is on the locus defined by (8) as $W_{\hat{p}_{x}}+W_{\hat{P}_{x}^{*}}^{*} / \lambda_{x}^{*}=0$, with the symmetric condition holding as well for good $y$. By Proposition 3, a tariff pair can be implemented under reciprocity if and only if it satisfies either $\left\{W_{\hat{p}_{x}}=0, W_{\hat{p}_{y}^{*}}^{*}=0, W_{\hat{p}_{x}^{*}}^{*}\right.$, $\left.W_{\hat{p}_{y}} \geq 0\right\}$ or $\left\{W_{\hat{p}_{y}}=0, W_{\hat{p}_{x}^{*}}^{*}=0, W_{\hat{p}_{y}^{*}}^{*} \leq 0, W_{\hat{p}_{x}} \leq 0\right\}$. It thus follows that an efficient trade agreement can be implemented under reciprocity if and only if it satisfies $\boldsymbol{W}_{\hat{p}_{x}}=0=\boldsymbol{W}_{\hat{p}_{x}^{*}}^{*}$ and $W_{\hat{p} y}=0=W_{\hat{p}_{x}^{*}}^{*}$. But this is by (9) the definition of politically optimal tariffs. $Q \cdot E \cdot D$.

Hence, our framework can provide a logic to the representation of reciprocity found in GATT, but only if governments seek through GATT to implement the tariffs that remain when the terms-of-trade motivations from each government's Nash trade policies are eliminated: No other efficient set of tariffs can be implemented under reciprocity. 25

The main ideas are illustrated in Figure 5. This figure depicts the iso-efficiency line through the Nash point (labeled $\boldsymbol{t}^{N} \rightarrow \boldsymbol{t}^{N}$ ), the iso-efficiency line through the politically optimal point (i.e., the efficiency locus, labeled $\iota^{E} \rightarrow \iota^{E}$ ), and iso-welfare contours for the importing and exporting government. At a political optimum (labeled $P O$ in the figure), these iso-welfare contours are tangent to each other and to a world price line (labeled $p_{P O}^{\mathcal{w}}$ ) and the corresponding tariffs can be implemented under reciprocity. At a point on the efficiency locus such as that labeled $H(L)$, the iso-welfare contours are again tangent to each other but now the iso-world-

\footnotetext{
${ }^{25}$ Terms-of-trade motivations lead all governments to protect against imports too readily and to promote exports too timidly relative to the efficient levels of intervention given their preferences. Hence, Proposition 4 implies that import tariffs will be reduced in an efficient trade agreement that is implemented under reciprocity, but that export subsidies should be encouraged. This suggests that GATT's attempt to restrict export subsidies may be misplaced, since such attempts work against the basic task of expanding trade volumes from inefficiently low levels. In fact, the treatment of subsidies in GATT has long been a source of controversy and confusion. GATT originally contained no rules on the use of export subsidies, and then later introduced and repeatedly tightened its rules on allowable export subsidies and on subsidies more broadly (Jackson, 1989, pp. 249-273). For an analysis of the treatment of export subsidies in international trade agreements, see Bagwell and Staiger (1996b).
} 
price line through this point is steeper (flatter) than their common tangency. The tariffs associated with point $H(L)$ are not politically optimal, and they cannot be implemented under reciprocity as the importing (exporting) government will desire less liberalization than is required to reach the efficiency locus along this world price line. ${ }^{26}$

We have now provided an answer to our second question, finding that the principle of reciprocity serves to "undo" the terms-of-trade driven restrictions in trade volume that occur when governments pursue unilateral trade policies. In this way, reciprocity acts as a principle that guides member governments to a more efficient outcome. We turn next to our third and fourth questions and consider the principle of non-discrimination and preferential agreements.

\section{Reciprocal Trade Agreements in a Many-Country Framework}

We now extend the two-country model of the previous section to a many-country setting. We continue to assume that there is a single home country (no*), but we now allow the home country to import good $x$ from three separate foreign sources $\left(* 1, * 2,{ }^{*} 3\right)$. For simplicity, we focus on trade among the four countries in good $x$ alone.

\section{A. Model}

In this subsection, we present our basic assumptions, determine the market-clearing prices and trade volumes, and define the government welfare functions.

Basic Assumptions: The good $x$ is produced and demanded in each of the four countries, but the demand and supply functions are such that the domestic country is a natural importer of good $x$ while the three foreign countries are natural exporters of this good. Letting $p$ denote the local price of $x$ in the domestic market, the domestic demand and supply functions are respectively represented with the functions $D(p)$ and $Q(p)$. We assume that the three foreign countries are symmetric. Denoting the local price of good $x$ in foreign country $j$ as $p^{* j}$, the corresponding demand and supply in foreign country $j$ are given as $D^{*}\left(p^{*} j\right)$ and $Q^{*}\left(p^{*} j\right)$. We represent the domestic import volume as $M(p) \equiv D(p)-Q(p)$, while the export volume of

\footnotetext{
${ }^{26}$ While we do not specify the bargaining environment in the first stage of the Bilateral Negotiation Game, it is immediate that any first-stage bargaining structure that yields an efficient outcome to the Bilateral Negotiation Game must implement politically optimal tariffs. For instance, it can be shown that if the Generalized Nash Bargaining solution is applied to the first stage of the Bilateral Negotiation Game, politically optimal tariffs will be the unique outcome provided that (i). international lump-sum transfers are feasible, or (ii). bargaining power is sufficiently balanced across governments.
} 
foreign country $j$ is denoted as $E^{*}\left(p^{*} j\right) \equiv Q^{*}\left(p^{*} j\right)-D^{*}\left(p^{*} j\right)$. Finally, the respective profit functions are given as $\Pi(p)$ and $\Pi^{*}\left(p^{* j}\right)$.

While we describe our main findings in general terms, it is sometimes convenient to refer to a concrete version of the model. To this end, we assume that $D(p)=1-p, Q(p)=p / 2$, $D^{*}\left(p^{*}\right)=\left(1-p^{*} j\right) / 3$ and $Q^{*}\left(p^{*}\right)=p^{*} j / 3$, from which it follows that $M(p)=1-3 p / 2, E^{*}\left(p^{*} j\right)=$ $\left[2 p^{*} j_{-1}\right] / 3, \Pi(p)=(p)^{2 / 4}$ and $\Pi^{*}\left(p^{*} j\right)=\left(p^{*}\right)^{2 / 6}$.

Price Determination: Let $\boldsymbol{\tau}^{j}$ denote the specific import tariff on home imports of $x$ from foreign country $j$, and let $\tau^{* j}$ similarly denote the specific export subsidy on exports of $x$ from foreign country $j$. Provided that trade taxes do not prohibit trade, the local prices must obey the following arbitrage and market-clearing conditions:

$$
\begin{aligned}
& p=p^{* j}+\tau^{j}-\tau^{* j} \\
& M(p)=\sum_{j=1}^{3} E^{*}\left(p^{* j}\right) .
\end{aligned}
$$

The market-clearing prices again depend upon the net tariffs. Letting $\iota{ }^{j} \equiv \tau^{j}-\tau^{* j}$ denote the net tariff between the domestic country and foreign country $j$, we may thus represent the marketclearing local prices as $p\left(\iota^{1}, \iota^{2}, \iota^{3}\right)$ and $p^{*}\left(\iota^{1}, \iota^{2}, \iota^{3}\right)$. The domestic market-clearing local price, $p\left(\iota^{1}, \iota^{2}, \iota^{3}\right)$, is increasing in each argument, while the foreign market-clearing local price, $p^{*}\left(\iota^{1}, \iota^{2}, \iota^{3}\right)$, is decreasing in $\iota^{j}$ and increasing in its other arguments.

Turning now to the world price, we begin with the observation that each bilateral trading relationship is associated with its own "world" price. Letting $p^{w j}$ denote the world (untaxed) price of $x$ between the home country and foreign country $j$, we have that the world price satisfies $p=p^{w j}+\tau^{j}$ and $p^{* j}=p^{w j}+\tau^{* j}$. Using the solutions for the market-clearing local prices, we may express the world price as $p^{w j}\left(\tau^{j}, \iota^{l}, \iota^{2}, \iota^{3}\right) .27$ This function is decreasing in its first argument and increasing in all of its other arguments. Market-clearing local prices also may be expressed as functions of world prices: $\hat{p}\left(\tau^{j}, p^{w j}\left(\tau^{j}, \iota^{l}, \iota^{2}, \iota^{3}\right)\right)=p^{w j}\left(\tau^{j}, \iota^{1}, \iota^{2}, \iota^{3}\right)+\tau^{j}$ and $\hat{p}^{* j}\left(\tau^{j}, p^{w j}\left(\tau^{j}, \iota^{1}, \iota^{2}, \iota^{3}\right)\right)=p^{w j}\left(\tau^{j}, \iota^{1}, \iota^{2}, \iota^{3}\right)+\tau^{* j}$. Finally, we observe that if domestic tariffs conform to MFN, then $\tau^{l}=\tau^{2}=\tau^{3} \equiv \tau$ and therefore a single world price obtains with $p^{w 1}=p^{w 2}=p^{w 3} \equiv p^{w}$.

\footnotetext{
${ }^{27}$ Explicit solutions for the various prices can be found in the Appendix.
} 
Trade Volumes: With the market-clearing local and world prices now determined, it is possible to provide the condition under which the market-clearing trade volumes are positive. Exploiting the specific structure of the model, it can be shown that trade policies are nonprohibitive provided that

$$
\iota^{j}<(4 / 7)\left[1 / 8+\sum_{i=1}^{3} \iota^{i / 3}\right], \text { for } j=1,2,3
$$

Thus, trade volumes are positive provided that the net tariffs are not too high.

Government Objectives: As in the previous section, governments are assumed to maximize a weighted sum of consumer surplus, producer surplus and tariff revenue. Since each foreign country trades only with the home country, the objectives of each foreign country can be written as a function of its local price and the world price between it and the home country. Specifically, the welfare function for the government of foreign country $j$ is

$$
W^{* j}\left(\hat{p}^{* j}, p^{w j}\right) \equiv \int_{\hat{p}^{* j}}^{1} D\left(p^{* j}\right) d p^{* j}+\gamma_{e}^{j} \Pi^{*}\left(\hat{p}^{* j}\right)-\left[\hat{p}^{* j}-p^{w j}\right] E^{*}\left(\hat{p}^{* j}\right) .
$$

Notice that the political-economy weight placed upon the export sector may differ across the foreign governments.

While the foreign-government welfare functions are similar to those derived in the previous section, the home government now faces three trading partners against which it can discriminate, and so its welfare function is more complicated. The home-government welfare function is defined as

$$
W\left(\hat{p}, \hat{p}^{* I}, \hat{p}^{* 2}, \hat{p}^{* 3}, p^{w 1}, p^{w 2}, p^{w 3}\right) \equiv{\underset{\hat{p}}{\hat{p}}}^{l} D(p) d p+\gamma_{m} \Pi(\hat{p})+\sum_{j=1}^{3}\left[\hat{p}-p^{w j}\right] E^{*}\left(\hat{p}^{* j}\right) .
$$

Observe that the home-government welfare function depends upon the home local price, the world prices and the foreign local prices.

The welfare functions reveal an interesting pattern of externalities. As before, externalities pass between countries through the corresponding world prices. Now, however, there is an additional externality channel through which a foreign tariff can affect home welfare. For any fixed volume of imports (i.e., for any fixed home price), the home government prefers 
that more of the given import volume is allocated to the foreign country against which it has the highest tariff. Thus, foreign local prices, which determine foreign export flows, exert a separate externality on home welfare, even when the local home and world prices are fixed. Notice that this local price externality is removed when the home government adopts nondiscriminatory tariffs, in which case home tariff revenue can be expressed simply as a function of the home local price and the single world price (i.e., as $\left.\left(\hat{p}-p^{w}\right] M(\hat{p})\right)$.

The home welfare function also can be written as a function of the home local price and a composite variable, $\hat{T}=\hat{T}\left(\hat{p}^{*} 1, \hat{p}^{* 2}, \hat{p}^{* 3}, p^{w 1}, p^{w 2}, p^{w 3}\right)$, that represents the home country's multilateral terms of trade. To this end, we define $\hat{T}$ as a weighted average of the world prices that the home country faces:

$$
\hat{T} \equiv \frac{\sum_{i=1}^{3} E^{*}\left(\hat{p}^{*} i\right) x p^{w i}}{\sum_{i=1}^{3} E^{*}\left(\hat{p}^{*}\right)}
$$

It is now direct to verify that home welfare may be re-written as

$$
W(\hat{p}, \hat{T}) \equiv \int_{\hat{p}}^{l} D(p) d p+\gamma_{m} \Pi(\hat{p})+[\hat{p}-\hat{T}] M(\hat{p}) .
$$

Thus, externalities associated with foreign tariffs travel through the foreign local and world prices to the home multilateral terms of trade, $\hat{T}$, and from there to home welfare. Note that $\hat{T}=$ $p^{w}$ under MFN tariffs for the home country, confirming that the world price is then the only channel through which externalities flow to the home country.

\section{B . Nash Equilibria}

As in the previous section, we start by considering the static tariff game, in which the domestic government selects a tariff policy, $\left(\tau^{l}, \tau^{2}, \tau^{3}\right)$, in order to maximize its welfare, $W$, at the same time that each foreign government $j$ chooses its tariff policy, $\tau^{*} j$, to maximize its welfare, $W^{*} j$. Having offered a thorough interpretation of the Nash equilibrium in the previous section, we simply present here the general best-response conditions that Nash trade policies must satisfy. We also focus only on interior Nash equilibria in which trade takes place. 
Maximizing $W$ with respect to $\tau^{j}$ and $W^{* j}$ with respect to $\tau^{* j}$ for each $j$ defines implicitly the domestic- and foreign-government best-response tariffs:

(10a). Home:

$W_{\hat{p}}+\chi^{j} W_{\hat{T}}=0$, for $j=1,2,3$

(10b). Foreign:

$$
W_{\hat{p}^{* j}}^{* j}+\varkappa^{* j} W_{p w j}^{* j}=0, \text { for } j=1,2,3 \text {, }
$$

where $\tilde{\lambda}^{j} \equiv\left[d \hat{T} / d \tau^{j}\right] /\left[d \hat{p} / d \tau^{j}\right]$ and $\chi^{* j} \equiv\left[d p^{w j} / d \tau^{* j}\right] /\left[d \hat{p}^{*} j / d \tau^{*} j\right]$. Note that it is only the home government's concern over the world price effects of its intervention that lead it to discriminate against its foreign trading partners: any local price achieved under discriminatory tariffs could also be achieved under an MFN tariff that allows the same multilateral import volume. In particular, since $d \hat{p} / d \tau^{j}$ is constant and identical across $j$ in our linear model, it follows that the home government's best-response tariffs are set so as to equate their marginal effects on the home-country's terms of trade $\left(d \hat{T} / d \tau^{i}=d \hat{T} / d \tau^{k}\right.$ for $\left.\{i, k\}=1,2,3\right)$, thereby achieving maximal terms-of-trade improvement for any local price through tariff intervention. From the implicit equations given in (10a) and (10b), it is straightforward to solve for the six Nash tariffs that arise when each government selects a best-response tariff.

\section{Reciprocal Trade Agreements}

We next characterize the tariff combinations that maximize joint welfare. A general perspective can be offered with reference to the tariff that the home country places on imports from foreign country $j$. The efficiency condition that this tariff must satisfy is given by

$$
W_{\hat{p}} \frac{d \hat{p}}{d \tau^{\mathrm{j}}}+W_{\hat{T}} \frac{d \hat{T}}{d \tau^{\mathrm{j}}}+\sum_{i=1}^{3}\left\{W_{\hat{p}^{* i}}^{* i} \frac{d \hat{p}^{*_{i}}}{d \tau^{\mathrm{j}}}+W_{p w i}^{* i} \frac{d p^{w i}}{d \tau^{\mathrm{j}}}\right\}=0 .
$$

To interpret this condition further, we recall that the home tariff affects the multilateral terms of trade through its effect on world prices and local foreign prices:

$$
\frac{d \hat{T}}{d \tau^{\mathrm{j}}}=\sum_{i=1}^{3}\left\{\frac{\partial \hat{T}}{\partial \hat{p}^{* i}} \frac{d \hat{p}^{* i}}{d \boldsymbol{\tau}^{\mathrm{j}}}+\frac{\partial \hat{T}}{\partial p^{w i}} \frac{d p^{w i}}{d \tau^{\mathrm{j}}}\right\}
$$

Using $W_{\hat{T}}=-M(\hat{p}), \partial \hat{T} / \partial p^{w i}=E^{*}\left(\hat{p}^{* i}\right) / M(\hat{p})$ and $W_{p w i}^{* i}=E^{*}\left(\hat{p}^{* i}\right)$, it is now direct to see that the efficiency condition can be written as

(11). $W_{\hat{p}} \frac{\mathrm{d} \hat{p}}{d \tau^{\mathrm{j}}}+W_{\hat{T}} \cdot \sum_{i=1}^{3} \frac{\partial \hat{T}}{\partial \hat{p}^{*_{i}}} \frac{d \hat{p}^{*_{i}}}{d \tau^{\mathrm{j}}}+\sum_{i=1}^{3} W_{\hat{p}^{* i}}^{* i} \frac{d \hat{p}^{*_{i}}}{d \tau^{\mathrm{j}}}=0$. 
Notice that the world price movements are again eliminated from the efficiency condition. Comparing efficiency condition (11) with the best-response conditions (10a) and (10b), we see that Nash tariffs are once more inefficient, since the selection of these tariffs is motivated by the consequent movements in the world prices.

The novel feature of the multi-country model concerns the connection between the local foreign price and the home-country multilateral terms of trade. This local-price externality corresponds to the second term in (11). If home tariffs are discriminatory, so that the multilateral terms of trade depends upon local foreign and world prices, then this local-price externality is non-zero. Let us again define politically optimal tariffs as the tariffs that would be attained if the terms-of-trade motivations from each government's Nash trade policy choices were eliminated. In the present model, these tariffs are implicitly defined by

(12). $W_{\hat{p}}=0=W_{\hat{p}^{* j}}^{* j}$, for $j=1,2,3$.

Returning now to the efficiency condition (11) above and using (12), we see that politically optimal tariffs are inefficient when the home tariffs are discriminatory. Intuitively, even if the foreign governments are not motivated by the world-price consequences of their trade policy choices, the local prices that their tariffs imply determine foreign export volumes and thereby impose an externality upon the home government if its tariffs are discriminatory.

On the other hand, if home tariffs satisfy MFN, then the multilateral terms of trade is simply the (common) world price, and the local-price-externality term in (11) is zero. It follows that a multilateral trade agreement is efficient if the terms-of-trade motivations are eliminated from each government's Nash tariff selection and all tariffs conform to MFN. In other words, politically optimal tariffs that also satisfy MFN are efficient, but politically optimal tariffs that are discriminatory are inefficient. ${ }^{28}$ The central idea is that, under MFN, externalities are channeled only through the world price, and so efficiency is achieved if terms-of-trade motivations are eliminated from each government's Nash trade policy choices.

\footnotetext{
${ }^{28}$ The requirement of political optimality as given in (12) represents four restrictions placed on a total of six tariffs. Thus, there will be many politically optimal tariff combinations. When tariffs are required to satisfy MFN, then there are only four tariffs in total, and so among the set of politically optimal tariffs there is a unique combination of tariffs that are also MFN.
} 


\section{Reciprocity, Non-discrimination and Preferential Agreements}

Having characterized the Nash, efficient and politically optimal trade policies in our many-country framework, we now use this framework in order to evaluate the principles of reciprocity and non-discrimination in a multilateral trade agreement. We also assess the implications of preferential agreements for a multilateral trading system built upon these principles. We begin by exploring the link between reciprocity and non-discrimination.

\section{A. Reciprocity and Non-discrimination}

We are again interested in characterizing the conditions under which an efficient multilateral trade agreement can be implemented under reciprocity. We thus now extend to the multi-country setting the definition of substantially equivalent concessions. We will say that, if a country proposes to increase a previously negotiated tariff, a proposed set of tariff increases by its trading partner(s) will constitute a withdrawal of substantially equivalent concessions provided that, when valued at existing world prices, the proposed tariff increases together bring about equal reductions in the volume of each country's imports and exports. Given a

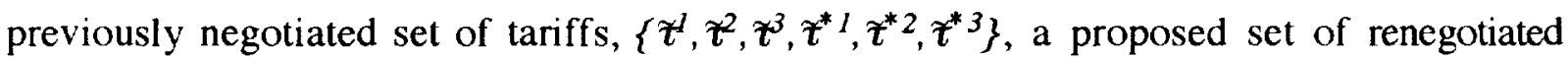
tariffs, $\left\{\overline{\boldsymbol{\tau}}^{1}, \overline{\boldsymbol{\tau}}^{2}, \overline{\boldsymbol{\tau}}^{3}, \overline{\boldsymbol{\tau}}^{* 1}, \overline{\boldsymbol{\tau}}^{* 2}, \overline{\boldsymbol{\tau}}^{*}\right\}$, will represent an initial tariff withdrawal by one country and a withdrawal of substantially equivalent concessions by its trading partner(s) provided that

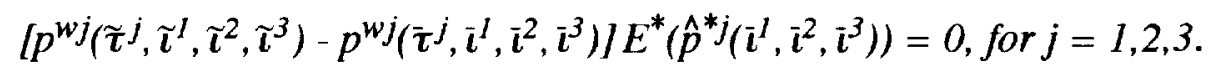

This condition is satisfied by any set of tariff increases that leaves world prices unchanged. 29 Therefore, as in the two-country setting of the previous section, reciprocity ensures that any renegotiation will be over the set of outcomes which are feasible under the world prices that were established in the original negotiations.

We therefore extend the Bilateral Negotiation Game of the previous section to our multicountry model. Formally, we define the Multilateral Negotiation Game as follows:

\footnotetext{
${ }^{29}$ This condition can be derived with the same steps described in footnote 18 , where the numeraire good $z$ again ensures that trade is balanced. The presence of a single non-numeraire good in our multi-country model accounts for the slightly stronger condition defining the withdrawal of substantially equivalent concessions as compared to the condition derived above for the two-country model. In either case, renegotiation takes place over the same set of outcomes: those that are feasible under the world prices that were established in the original negotiations.
} 
Stage 1: $\quad$ Governments bargain over the set of bilateral world prices.

Stage 2: $\quad$ Each government announces a set of tariffs consisting of tariff levels for itself and tariff levels for the remaining three countries that together yield the set of bilateral world prices from stage 1 .

Stage 3: $\quad$ If each government announces the same set of tariffs in stage 2, then this set of tariffs is implemented as the outcome of the negotiation. If the set of tariffs announced by any government in stage 2 differs from that announced by any other, then countries implement the set of tariffs which achieves the maximum trade volume subject to the constraint that no country engages in more (multilateral) trade than was implied by its announcement.

In analogy with the two-country model of the previous section, we will say that a set of tariffs $\left\{\hat{\boldsymbol{\tau}}^{1}, \overline{\boldsymbol{\tau}}^{2}, \overline{\boldsymbol{\tau}}^{3}, \overline{\boldsymbol{\tau}}^{* 1}, \overline{\boldsymbol{\tau}}^{* 2}, \overline{\boldsymbol{\tau}}^{*}\right\}$ can be implemented under reciprocity if there exists a set of bilateral world prices $\left\{\bar{p}^{w 1}, \bar{p}^{w 2}, \bar{p}^{w 3}\right\}$ such that any Nash equilibrium of the subgame corresponding to stages 2 and 3 of the Multilateral Negotiation Game yields the outcome $\left\{\bar{\tau}^{l}, \overline{\boldsymbol{\tau}}^{2}, \overline{\boldsymbol{\tau}}^{3}, \overline{\boldsymbol{\tau}}^{* 1}, \overline{\boldsymbol{\tau}}^{* 2}, \overline{\boldsymbol{\tau}}^{* 3}\right\}$ when $\left\{\bar{p}^{w l}, \bar{p}^{w 2}, \tilde{p}^{w 3}\right\}$ is selected in stage 1 .

It can be shown that the analog to Proposition 3 holds in our multi-country setting. We state it here in terms of our multi-country notation for completeness:

Proposition 5: A set of tariffs $\left\{\overline{\boldsymbol{\tau}}^{l}, \overline{\boldsymbol{\tau}}^{2}, \overline{\boldsymbol{\tau}}^{3}, \bar{\tau}^{* 1}, \overline{\boldsymbol{\tau}}^{* 2}, \overline{\boldsymbol{\tau}}^{*}\right\}$ can be implemented under reciprocity if and only if it satisfies either $\left\{W_{\hat{p}}=0 ; W_{\hat{p}^{* j}}^{* j} \geq 0\right.$ for each $\left.j\right\}$ or $\left\{W_{\hat{p}} \leq 0 ; W_{\hat{p}^{* j}}^{* j}=0\right.$ for each $\left.j\right\}$.

We now determine whether an efficient agreement can be implemented under reciprocity in the presence of tariff discrimination. Our result is contained in the next proposition:

Proposition 6: An efficient multilateral trade agreement can be implemented under reciprocity if and only if it is characterized by tariffs which conform to the principle of MFN and are politicallyoptimal.

Looking to Proposition 5 and (11), it is clear that a set of tariffs that is politically optimal and that satisfies MFN can be implemented under reciprocity and is efficient. In the Appendix, we show that the reverse implication holds as well.

The broader idea is that the principle of reciprocity serves well as a means to promote efficient agreements when externalities travel only through the world price. When governments abide by the principle of MFN, externalities indeed do travel in only this fashion, and so reciprocity and non-discrimination work in concert as principles that guide governments to 
efficient trade agreements. In response to our third question, this explains why the principle of non-discrimination can advance the mutual goals of member governments that participate in a multilateral trading agreement that also endorses the principle of reciprocity. We now develop an analysis of preferential agreements in order to address our final question.

\section{B . Preferential Agreements}

We consider two forms of preferential agreements. We will say that the home country forms a free trade area with foreign country $i$ if $\tau^{i}=\tau^{* i}=0$ and $\tau^{j}>0$ for some $j \neq i$. The feature of a customs union that distinguishes it from a free trade area is that, in addition to eliminating internal barriers, the members of a customs union adopt a common external tariff policy as well. Hence, the tariff decisions of customs union members are centralized, and so the objectives of the tariff authorities in the customs union must be defined. If the home country forms a customs union with foreign country $i$, we define the objectives of the customs union as the sum of the objectives of its members: $U^{*_{i}} \equiv W+W^{* i}$.

Consider first the introduction of free trade agreements. In particular, suppose that the home government establishes a free trade agreement with foreign country $i$. We may now express an immediate implication of Proposition 6:

Proposition 7: An efficient multilateral trade agreement can not be implemented under reciprocity in the presence of a free trade agreement.

Proposition 7 indicates that free trade agreements are fundamentally at odds with a multilateral system that is built on the pillars of reciprocity and non-discrimination: The legitimacy of the principle of reciprocity at the multilateral level is undermined if exceptions from the principle of MFN are granted for the formation of free trade agreements. Intuitively, the politically optimal tariffs are efficient when externalities travel only through world prices, but externalities travel through local prices as well when tariffs are discriminatory (as when some countries form a free trade agreement). The efficiency properties of politically optimal MFN external tariffs are thus lost when a free trade agreement is in place.

We next consider the formation of a customs union between the home country and foreign country $i$. We can not immediately conclude from Proposition 6 that the presence of a customs union is incompatible with the pursuit of an efficient multilateral trade agreement through the principle of reciprocity. This is because the situation in which a customs union 
exists represents a different modeling environment than considered above, as the number of policy-setting countries has been reduced from four to three. Nevertheless, Proposition 6 is instructive. Suppose that two countries that form a customs union are symmetric and that they eliminate the internal tariff for trade within the union. Then, in a sense, the union is analogous to a single country in the analysis above, suggesting that the principle of reciprocity can then deliver an efficient agreement in the presence of a customs union if and only if all external tarifs satisfy MFN and are politically optimal.

To explore this idea, we require a notion of symmetry. Observe that if the home country and foreign country $i$ remove internal tariffs (i.e., if $\boldsymbol{\tau}^{i}=\boldsymbol{\tau}^{* i}=0$ ), then there must be a common price within the union (i.e., $\hat{p}=\hat{p}^{* i}$ ). Not surprisingly, a common local price within the union is inefficient unless the home import-competing and foreign-country- $i$ exporting firms have political weights that are in some sense symmetric. In the Appendix, we exploit the specific structure of our model and demonstrate that the common local price that results from a removal of internal barriers is internally inefficient unless the weights satisfy the following relationship: $3 \gamma_{e}^{i}-2 \gamma_{m}=1$. When this relationship holds, we say that the domestic country is a natural integration partner with foreign country $i$, as the removal of internal trade barriers is then internally efficient.

We can now state:

Proposition 8: An efficient multilateral trade agreement can be implemented under reciprocity in the presence of a customs union if and only if the members of the customs union are natural integration partners and the external tariffs of the customs union and the tariffs of all other countries conform to the principle of MFN and are politically optimal.

The proof of this proposition is found in the Appendix. Proposition 8 establishes that preferential agreements can be part of an efficient multilateral system that is based on reciprocity, but both the form of the preferential agreement and the circumstances under which it is appropriate are quite special. Thus, with respect to our fourth question, our framework offers only limited support for the view that preferential agreements are compatible with the efficient functioning of a multilateral system founded on reciprocity.

We summarize the results of this section with a final proposition: 
Proposition 9: An efficient multilateral trade agreement can be implemented under reciprocity in the presence of a preferential agreement if and only if the multilateral agreement is characterized as follows:

(i). Each country that is not a member of a preferential agreement must abide by the principle of non-discrimination (MFN) and set its tariffs at a level which is politically optimal; and

(ii). Each country that is a member of a preferential agreement must belong to a customs union between natural integration partners that sets its external tariffs in accordance with the principle of non-discrimination (MFN) and at a level which is politically optimal for the customs union.

\section{Conclusion}

We began this paper with four questions. First, what can governments hope to accomplish with reciprocal trade agreements? Second, given that free trade is not their stated objective, can governments nevertheless expect an arrangement that advocates reciprocal tariff liberalization to be mutually advantageous? Third, are their mutual goals best advanced by an agreement that eliminates discriminatory treatment? And fourth, once the principle of nondiscrimination is adopted, can exceptions to this principle be granted for the creation of preferential agreements without compromising the performance of the multilateral system?

Allowing that governments may have both political and economic motivations, we argue that the appeal of a reciprocal trade agreement rests on the elimination of the inefficiency associated with the terms-of-trade externality that arises when governments set their policies unilaterally. This externality induces governments to restrict trade more than is efficient, given their preferences. Arguing from this perspective, we find that the representation of reciprocity as found in GATT can enable governments to expand trade and achieve an efficient outcome. This is true, however, only if governments seek through GATT to implement the tariffs that are desired when the terms-of-trade motivations from each government's Nash trade policy choices are eliminated. In particular, we find that an efficient trade agreement can be implemented under reciprocity only if the agreement is characterized by such tariffs. We also discover a new link between the principles of reciprocity and non-discrimination (MFN) in an efficient multilateral trading system: A multilateral system built on the principle of reciprocity can implement an efficient agreement only if it also embraces the principle of non-discrimination.

With regard to preferential trading arrangements, an important departure of our focus from other work on the relationship between regionalism and the world trading system is that 
we do not analyze whether regionalism serves as a means to enable GATT to bring the world closer to free trade. Instead, our analysis takes a positive approach to the issue of regionalism within GATT, and we analyze whether GATT serves the interests of its member governments when it allows under Article XXIV exceptions to the principle of MFN for the purpose of creating preferential agreements. Our analysis suggests that the circumstances under which a preferential agreement can arise as part of an efficient agreement are limited. Preferential agreements can be part of an efficient multilateral system that is based on reciprocity, but both the form and the circumstances under which it is appropriate are quite special. The efficiency properties of a multilateral system based on reciprocity can be preserved when a preferential agreement is allowed only if the member countries are "natural integration partners" that seek to integrate fully by forming a customs union.

Fundamentally, our theory rests upon the hypotheses that governments care about the terms of trade and that they are able to influence the terms of trade with their trade policy choices. The former hypothesis demands that the terms-of-trade effects of trade policy choices influence the national cost of intervention in quantitatively important ways. In this regard, empirical studies by Goldberg (1995) and Berry, Levinsohn and Pakes (1994) offer strong support. These studies estimate the impacts of voluntary export restraints (VERs) imposed by the U.S. on Japanese automobiles in the 1980's. Both studies indicate that the terms-of-trade implications of the U.S. decision to restrict automobile imports from Japan with VERs (rather than with tariffs) increased by a substantial amount the cost to the U.S. of achieving the reduced import volumes. For example, comparing the actual VER policy with a hypothetical equivalenttariff policy - the difference reflecting the distinct world (untaxed) prices associated with each form of intervention - Berry, Levinsohn and Pakes (1994) calculate that the equivalent-tariff policy would have yielded revenue sufficient to turn what was a losing trade policy from the perspective of U.S. national income into a policy that would have generated a net gain to U.S. national income of $\$ 12.5$ billion. It is precisely this role of world prices to affect the international incidence of the cost of intervention that is the starting point of our theory. ${ }^{30}$

\footnotetext{
30 Our theory allows that a government might choose to offer protection even when the policy generates losses from a purely national income perspective, as the U.S. VERs against Japan evidently did, but it might be tempting to conclude that the "give-away" implicit in the U.S. choice to proceed with VERs rather than an equivalent-tariff policy suggests in fact that the U.S. did not care about terms-of-trade effects in this case. It must be remembered, however, that VERs represent a cooperative, negotiated approach to restricting trade, and that the U.S. "give-away" associated with its VERs was in fact in return for something from Japan: An understanding that Japan would not retaliate with trade restrictions of its own against U.S. imports. Therefore,
} 
It is also important to mention that additional empirical evidence exists in support of the latter hypothesis. ${ }^{31}$ Ultimately, an importing country has power over the terms of trade if foreign exporters incur some of the incidence of an import tariff (i.e., the full tariff is not passed through to domestic consumers). In this regard, we note that a large empirical literature exists that documents imperfect pass-through in the face of exchange rate shocks. It is thus natural to suppose that imperfect pass-through would also arise when the cost increase takes the form a tariff increase, and indeed Feenstra (1995) offers some empirical support for this supposition.

Finally, we call attention to two caveats that are associated with our analysis. First, we have examined reciprocity and non-discrimination as principles that guide governments from inefficient unilateral outcomes to the efficiency frontier. We have not considered here the possibility that factors may arise that prevent governments from reaching this frontier. A case of particular interest is where enforcement issues at the multilateral level (see, e.g., Dam, 1970) preclude governments from eliminating fully the terms-of-trade motivations from their trade policy choices under MFN. In such circumstances, the granting of exceptions to MFN for those country pairs that have additional enforcement ability to move further toward the efficiency frontier could enhance the overall efficiency of the multilateral agreement. As we show in other work (Bagwell and Staiger, forthcoming c), however, the enforcement implications of regional agreements for multilateral cooperation are complex, and there is as yet no basis from which to presume that such agreements necessarily enhance the overall efficiency of the multilateral agreement. ${ }^{32}$

the relevant policy alternative for the U.S. was not a set of unilateral tariff increases, which would surely have triggered a retaliatory "trade war" with Japan, but rather tariff changes that are consistent with the rules of GATT. In fact, one way to interpret the use of VERs is that, by giving away the tariff revenue and thereby ensuring that the importing government does not enjoy any terms-of-trade benefits as a by-product of its demand for reduced import volumes, these policy tools become an imperfect way of preventing cost-shifting motives from driving trade policy choices, and in this way substitute for the cooperative outcomes that GATT would have achieved had import tariffs been renegotiated under Article XXVIII (or temporarily raised under Article XIX).

${ }^{31}$ Support also can be found in the theoretical analysis of Gros (1987), who finds that even ostensibly small countries have some power over the terms of trade, if the industry is monopolistically competitive. We also note that our theory does not require that all countries have power to affect the world prices. Rather, our theory predicts that truly "small" countries would be extended MFN treatment in GATT but would not be required to offer reciprocal liberalization of their own, as their unilateral trade policy decisions are not influenced by inefficient cost-shifting motives (see Bagwell and Staiger, 1996a). This is, to some extent, what is accomplished in GATT through the "principle supplier" rule (see, for example, Dam, 1970, p. 61).

32 Other papers that consider the implications of allowing regional agreements for the ability to enforce multilateral cooperation include Bagwell and Staiger (forthcoming a, b), Bond and Syropolous (1996a,b) and Bond, Syropolous and Winters (1996). A broad perspective of the role of enforcement in multilateral trading arrangements is developed by Maggi (1996). 
Second, the government objective function that we have adopted throughout our analysis, while representative of the leading formulations of political-economy of trade policy, nevertheless may be too narrowly defined to capture many of the reasons that governments pursue preferential agreements in practice. In fact, regional integration initiatives are likely to reflect broader non-economic objectives such as military security or political stability that are not reflected in a country's national prices or terms of trade. Under this interpretation, GATT's willingness to allow Article XXIV exceptions may be rationalized in terms of broader noneconomic objectives that can be served by deeper integration among a subset of GATT members. In future work, we plan to explore the consequences of such government preferences for the role of preferential agreements in the multilateral trading system. 


\section{Appendix}

We prove here Propositions 6 and 8 . We begin by reporting various calculations for the many-country model:

$$
\begin{aligned}
& p\left(\iota^{1}, \iota^{2}, \iota^{3}\right)=(4 / 7)\left[1+\sum_{i=1}^{3} \iota^{i} / 3\right] \\
& p^{* j}\left(\iota^{1}, \iota^{2}, \iota^{3}\right)=(4 / 7)\left[1+\sum_{i=1}^{3} \iota^{i} / 3\right]-\iota^{j}, \text { for } j=1,2,3 \\
& p^{w j}\left(\tau^{j}, \iota^{1}, \iota^{2}, \iota^{3}\right)=(4 / 7)\left[1+\sum_{i=1}^{3} \iota^{i} / 3\right]-\tau^{j}, \text { for } j=1,2,3 \\
& W(\hat{p}, \hat{T})=1 / 2-\left(4-\gamma_{m}\right)(\hat{p})^{2} / 4-(1-3 \hat{p} / 2) \hat{T} \\
& W^{* j}\left(\hat{p}^{* j}, p^{w j}\right)=1 / 6-\left(3-\gamma_{e}^{j}\right)\left(\hat{p}^{* j}\right)^{2} / 6+\left(2 \hat{p}^{* j}-1\right) p^{w j / 3, \text { for } j=1,2,3} \\
& V\left(\iota^{l}, \iota^{2}, \iota^{3}\right)=1-\left(4-\gamma_{m}\right)(\hat{p})^{2} / 4-\sum_{i=1}^{3}\left(3-\gamma_{e}^{i}\right)\left(\hat{p}^{* i}\right)^{2} / 6,
\end{aligned}
$$

where $V \equiv W+\sum_{i=1}^{3} W^{* i}$. Choosing $\left(\iota^{1}, \iota^{2}, \iota^{3}\right)$ to maximize $V$, we find that the efficiency locus is characterized as

(A1). $\quad(2 / 3)\left(4-\gamma_{m}\right) \hat{p}=\left(3-\gamma_{e}^{I}\right)\left(\hat{p}^{* 1}\right)=\left(3-\gamma_{e}^{2}\right)\left(\hat{p}^{* 2}\right)=\left(3-\gamma_{e}^{3}\right)\left(\hat{p}^{* 3}\right)$.

Next, we find that the politically optimal tariffs are defined implicitly by

(A2). $W_{\hat{p}}=(3 / 4)\left[2 \hat{T}-(2 / 3)\left(4-\gamma_{m}\right) \hat{p}\right]=0$.

(A3). $W_{\hat{p}^{* j}}^{* j}=(1 / 3)\left[2 p^{w j}-\left(3-\gamma_{e}^{j}\right) \hat{p}^{* j}\right]=0$, for $j=1,2,3$.

Proof of Proposition 6: A comparison of (A2) and (A3) with the conditions of Proposition 5 reveals that politically optimal MFN tariffs can be implemented under reciprocity, while a comparison of (A2) and (A3) with (A1) reveals that politically optimal MFN tariffs are efficient. We now show that no other efficient trade agreement can be implemented under reciprocity. There are three cases to consider:

(i). An agreement that calls for tariffs that are politically optimal but do not conform with MFN. In this case, $\hat{T} \neq p^{w j}$ for $j=1,2,3$ and a comparison of (A2) and (A3) with (A1) implies that politically optimal tariffs can not be efficient. 
(ii). An agreement that calls for tariffs that conform to MFN but are not politically optimal. Then, Proposition 5 implies that either $\left\{2 p^{w}=(2 / 3)\left(4-\gamma_{m}\right) \hat{p} ; 2 p^{w} \geq\left(3-\gamma_{e}^{j}\right) \hat{p}^{* j}\right.$ for each $\left.j\right\}$, or $\left\{2 p^{w} \leq(2 / 3)\left(4-\gamma_{m}\right) \hat{p} ; 2 p^{w}=\left(3-\gamma_{e}^{j}\right) \hat{p}^{* j}\right.$ for each $\left.j\right\}$. If tariffs are not politically optimal, then by (A2) and (A3) at least one inequality for some $j$ is strict in each case, which by (A1) implies that the agreement can not be efficient.

(iii). An agreement that calls for tariffs that do not conform to MFN and that are not politically optimal. Proposition 5 implies that either $\left\{2 \hat{T}=(2 / 3)\left(4-\gamma_{m}\right) \hat{p} ; 2 p^{w j} \geq\left(3-\gamma_{e}^{j}\right) \hat{p}^{* j}\right.$ for $e a c h j\}$, or $\left\{2 \hat{T} \leq(2 / 3)\left(4-\gamma_{m}\right) \hat{p} ; 2 p^{w j}=\left(3-\gamma_{e}^{j}\right) \hat{p}^{* j}\right.$ for each $\left.j\right\}$. Let $k$ solve $\min _{i}\left\{p^{w i}\right\}$, and observe that $k$ is uniquely defined under discriminatory tariffs. Then, either $(2 / 3)\left(4-\gamma_{m}\right) \hat{p}=2 \hat{T}$ $>2 p^{w k} \geq\left(3-\gamma_{e}^{k}\right) \hat{p}^{* k}$ or $(2 / 3)\left(4-\gamma_{m}\right) \hat{p} \geq 2 \hat{T}>2 p^{w k}=\left(3-\gamma_{e}^{k}\right) \hat{p}^{* k}$. Using (A1), we conclude that the agreement can not be efficient. Q.E.D.

Proof of Proposition 8: To begin, we calculate the customs-union objective function:

$$
U^{* i} \equiv W+W^{* i}=2 / 3-\left(4-\gamma_{m}\right)(\hat{p})^{2} / 4-\left(3-\gamma_{e}^{i}\right)\left(\hat{p}^{* i}\right)^{2} / 6-(1-3 \hat{p} / 2) \hat{T}+\left(2 \hat{p}^{*_{i}}-1\right) p^{w i} / 3 .
$$

Suppose first that the home country and foreign country $i$ are natural integration partners (i.e., $\left.3 \gamma_{e}^{i}-2 \gamma_{m}=1\right)$. This condition is equivalent to $(2 / 3)\left(4-\gamma_{m}\right)=\left(3-\gamma_{e}^{i}\right)$, and so it follows from (A1) that the removal of internal trade barriers (which implies $\hat{p}=\hat{p}^{*}$ ) is internally efficient. Suppose further that all external tariffs conform to MFN and are set at their politically optimal levels. External tariffs then satisfy:

$$
\begin{aligned}
& U_{\hat{p}}^{* i}=(3 / 4)\left[2 p^{w}-(2 / 3)\left(4-\gamma_{m}\right) \hat{p}\right]=0 \\
& W_{\hat{p}^{* j}}^{* j}=(1 / 3)\left[2 p^{w}-\left(3-\gamma_{e}^{j}\right) \hat{p}^{* j}\right]=0, j \neq i .
\end{aligned}
$$

Referring to Proposition 5, we see that politically optimal MFN external tariffs can be implemented under reciprocity; in addition, we see from (A1) that, in the presence of a customs union between natural integration partners, politically optimal MFN external tariffs are efficient.

If the customs union members are not natural integration partners, then the elimination of internal trade barriers will be internally inefficient, and so the efficiency locus can not be reached. Finally, if the external tariffs are not set at their politically optimal levels in accordance with MFN, then the efficiency locus can not be reached under reciprocity by the proof of Proposition 6 (points (i), (ii) and (iii) as applied to external tariffs). Q.E.D. 


\section{References}

Bagwell, Kyle and Robert W. Staiger (1996a), "Reciprocal Trade Liberalization," NBER Working Paper No. 5488, March.

Bagwell, Kyle and Robert W. Staiger (1996b), "Strategic Export Subsidies and Reciprocal Trade Agreements: The Natural Monopoly Case," NBER Working Paper No. 5574, April.

Bagwell, Kyle and Robert W. Staiger (forthcoming a), "Multilateral Tariff Cooperation During the Formation of Customs Unions," Journal of International Economics.

Bagwell, Kyle and Robert W. Staiger (forthcoming b), "Multilateral Tariff Cooperation During the Formation of Regional Free Trade Areas," International Economic Review.

Bagwell, Kyle and Robert W. Staiger (forthcoming c), "Regionalism and Multilateral Tariff Cooperation," in John Piggott and Alan Woodland (eds.), International Trade Policy and the Pacific Rim, London: Macmillan.

Baldwin, Richard (1987), "Politically Realistic Objective Functions and Trade Policy," Economic Letters, 24, 287-290.

Berry, Steven, Levinsohn, James and Ariel Pakes (1994), "Voluntary Export Restraints on Automobiles: Evaluating a Strategic Trade Policy," mimeo.

Bhagwati, Jagdish (1991), The World Trading System at Risk. Princeton University Press: Princeton, New Jersey.

Bond, Eric W. and Costas Syropoulos (1996a), "Trading Blocs and the Sustainability of InterRegional Cooperation," in M. Canzoneri, W. Ethier and V. Grilli (eds.), The New Transatlantic Economy. Cambridge University Press: Cambridge.

Bond, Eric W. and Costas Syropoulos (1996b), "The Size of Trading Blocs: Market Power and World Welfare Effects," Journal of International Economics, 40, 411-38.

Bond, Eric W., Costas Syropoulos, and Winters, Alan A. (1996), "Deepening of Regional Integration and External Trade Relations, CPER Discussion Paper No. 1317.

Dam, Kenneth W. (1970), The GATT: Law and International Economic Organization. Chicago: University of Chicago Press.

Dixit, Avinash (1987), "Strategic Aspects of Trade Policy," in Truman F. Bewley, ed., Advances in Economic Theory: Fifth World Congress, New York: Cambridge Press.

Feenstra, Robert (1995), "Estimating the Effects of Trade Policy," in Gene M. Grossman and Kenneth Rogoff, eds., The Handbook of International Economics, Vol. 3, North Holland.

Goldberg, Penny Koujianou (1995), "Product Differentiation and Oligopoly in International Markets: The Case of the U.S. Automobile Industry," Econometrica 63, July, 891-951. 
Grossman, Gene and Elhanan Helpman (1994), "Protection for Sale," American Economic Review, 84, September, 833-50.

Grossman, Gene and Elhanan Helpman (1995), "Trade Wars and Trade Talks," Journal of Political Economy, 103, August, 675-708.

Jackson, John H. (1989), The World Trading System. Cambridge: The MIT Press.

Johnson, Harry G. (1953-45), "Optimum Tariffs and Retaliation," Review of Economic Studies, 21, no. 2, 142-53.

Krugman, Paul R. (1991), "The Mover Toward Free Trade Zones," in Policy Implications of Trade and Currency Zones, A Symposium Sponsored by the Federal Reserve Bank of Kansas City. Jackson Hole, Wyoming, August 22-24.

Maggi, Giovanni and Andres Rodriguez-Clare (1996), "The Value of Trade Agreements in the Presence of Political Pressures," mimeo, May.

Maggi, Giovanni (1996), "The Role of Multilateral Institutions in International Trade Cooperation," mimeo, December.

McMillan, John (1989), "A Game-Theoretic View of International Trade Negotiations: Implications for Developing Countries," in John Whalley, ed., Developing Countries and the Global Trading System: Volume I. MacMillan.

McMillan, John (1986), Game Theory in International Economics. New York: Harwood.

Mill, John Stuart (1844), Essays on Some Unsettled Questions of Political Economy. London: Parker.

Scitovsky, Tibor (1942), "A Reconsideration of the Theory of Tariffs," Review of Economic Studies, 9.

Staiger, Robert W. (1995), "International Rules and Institutions for Trade Policy," in Gene M. Grossman and Kenneth Rogoff, eds., The Handbook of International Economics, Vol. 3, North Holland.

Torrens, Robert (1844), The Budget: On Commercial and Colonial Policy. London: Smith, Edler. 


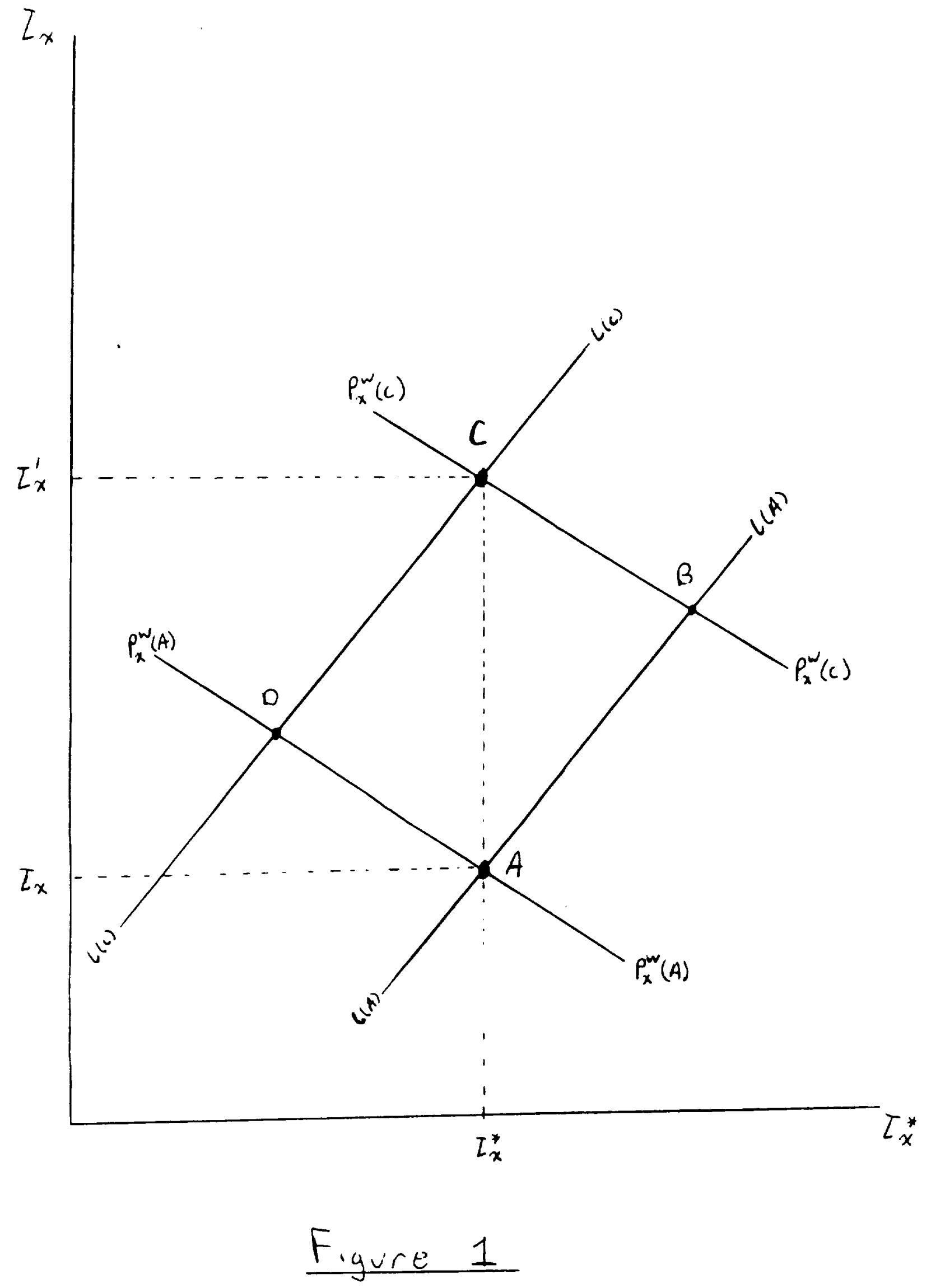




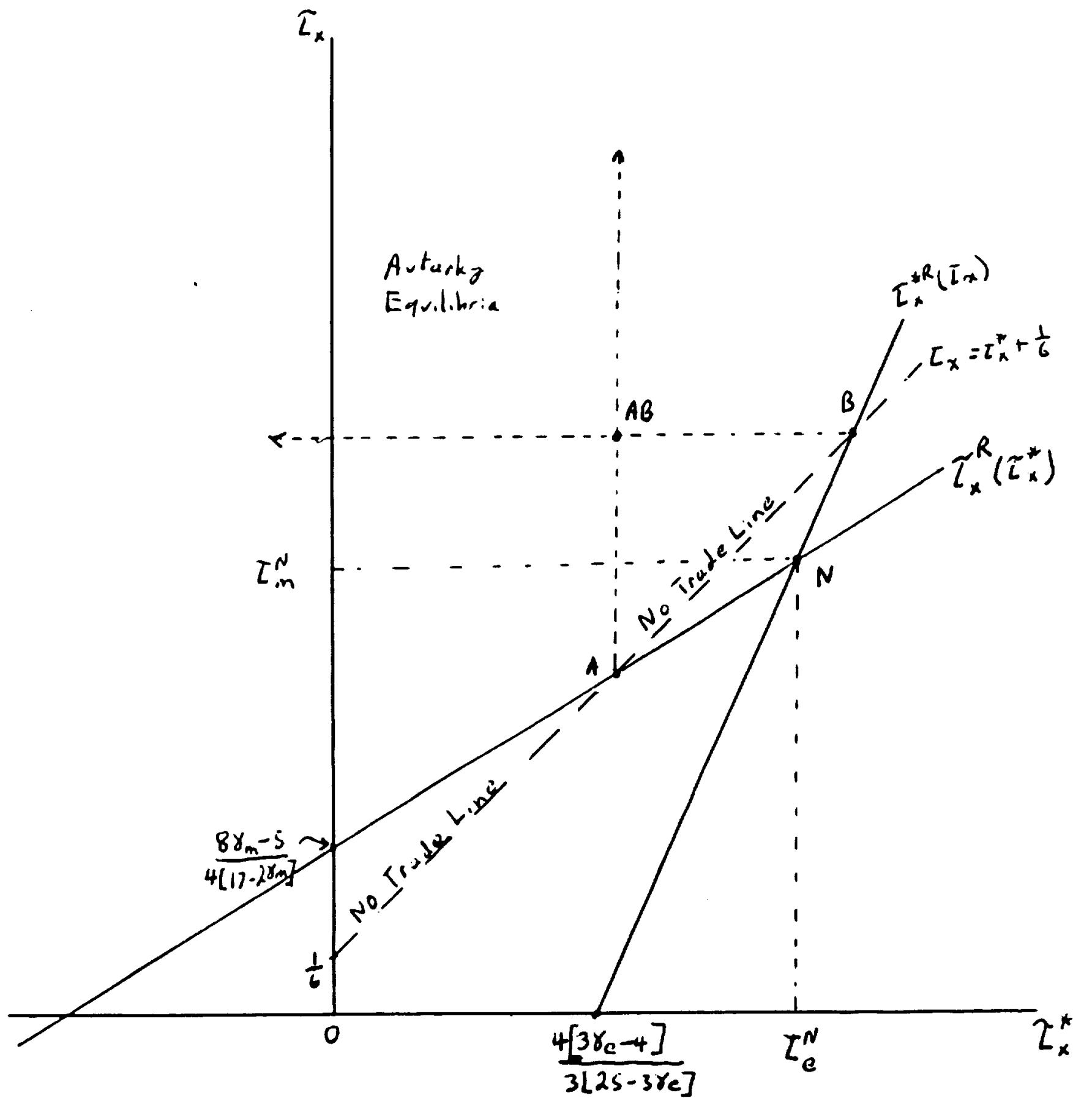

Figure 2 


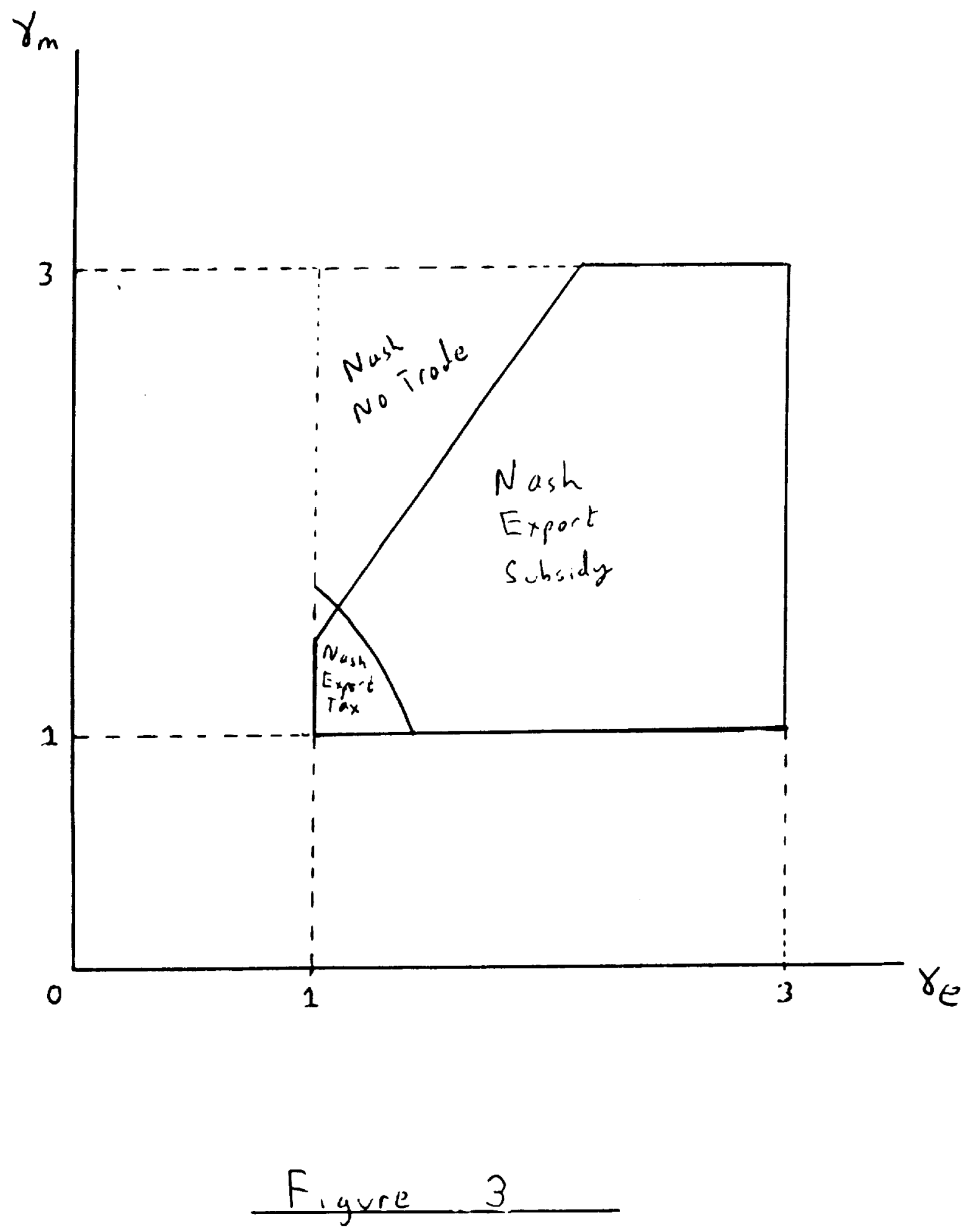




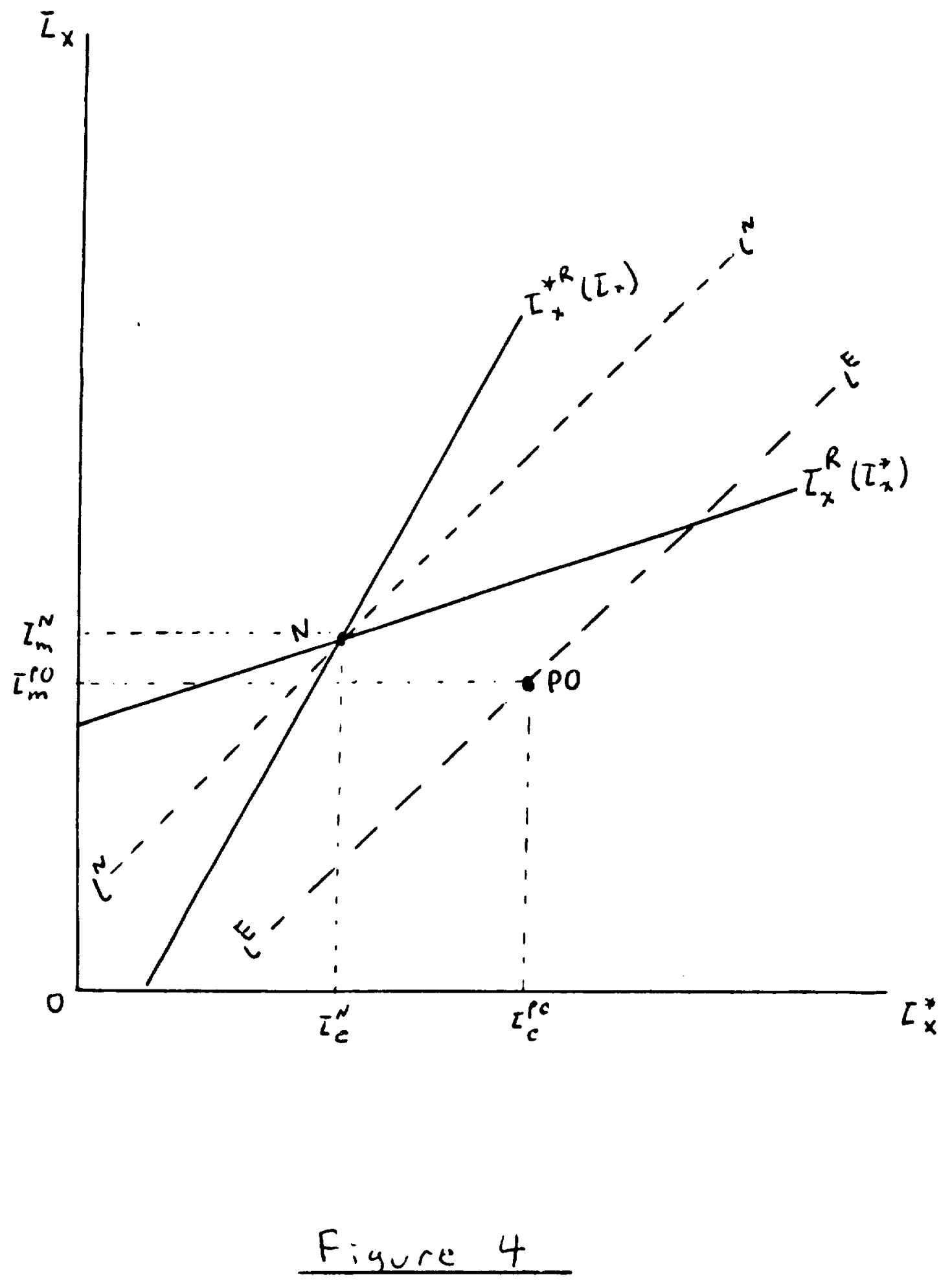




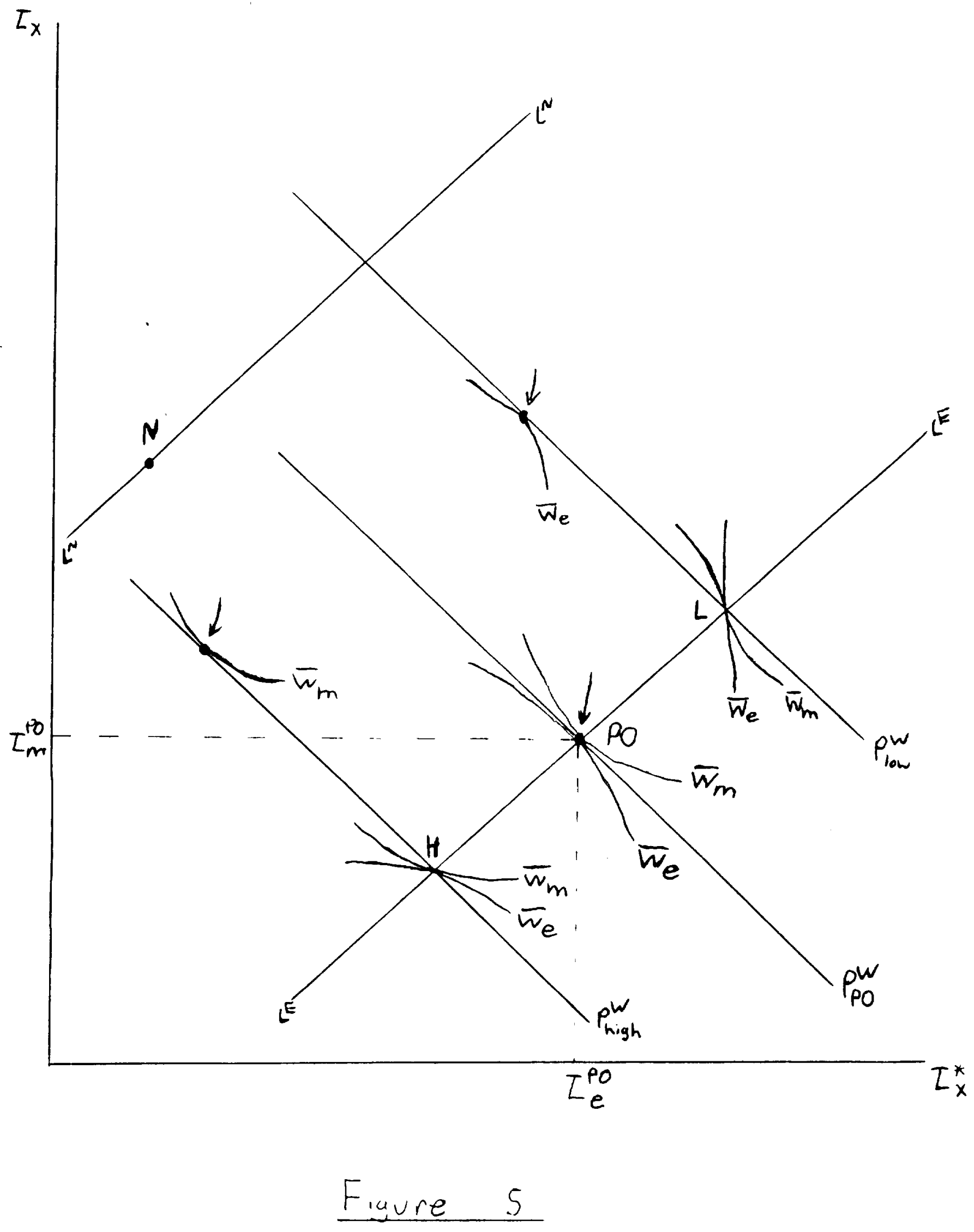

